INSTITUT NATIONAL DE LA STATISTIQUE ET DES ETUDES ECONOMIQUES

Série des Documents de Travail du CREST

(Centre de Recherche en Economie et Statistique)

$n^{\circ}$ 2003-26

Language and Foreign Trade

J. MELITZ

Les documents de travail ne reflètent pas la position de I'INSEE et n'engagent que leurs auteurs.

Working papers do not reflect the position of INSEE but only the views of the authors.

1 CREST-INSEE, University of Strathclyde and CEPR. 


\title{
LANGUAGE AND FOREIGN TRADE
}

\author{
Jacques Melitz* \\ CREST-INSEE, University of Strathclyde, and CEPR
}

First draft: July 2002

This draft: January 2003

\begin{abstract}
The significance of a common language in foreign trade hinges on translation as well as the ability to communicate directly. In fact, without admitting the facility of translation from one or two selected languages, it is impossible to explain adequately the impact of a common language on foreign trade. Linguistic diversity at home also promotes foreign trade. But the most significant linguistic influence of all on foreign trade may be the ability to read and write any language whatever. Besides these basic results, the study examines three special issues: whether English and other European languages are more effective than other languages in promoting foreign trade; whether there are substitution effects of a common language in foreign trade; and whether network externalities of language impinge on foreign trade.
\end{abstract}

\section{LANGAGE ET COMMERCE INTERNATIONAL}

Résumé: L'impact d'une langue commune sur le commerce international dépend non seulement de la communication directe, mais aussi de la traduction. En effet, sans admettre qu'il est possible d'obtenir sans difficulté dans sa propre langue les messages pertinents dans une ou deux autres langues, il est impossible d'expliquer de manière adéquate l'influence d'une langue commune sur le commerce international. La diversité linguistique interne, elle aussi, tend à promouvoir le commerce international. Mais parmi les influences linguistiques sur les échanges internationaux, la plus importante est peut-être la capacité de lire et écrire n'importe quelle langue. Hormis ces conclusions fondamentales, l'étude examine trois questions spéciales. Est-ce que l'anglais et les autres langues européennes sont particulièrement efficaces dans la promotion des échanges internationaux ? Il y a-t-il des effets de substitution sur les pays tiers dans la mesure où une langue commune encourage les échanges entre deux pays ? Enfin, des externalités de réseau de langage se manifestent-elles dans le commerce international?

JEL Classification: F10, F40

Keywords: language, foreign trade, gravity model

* Many thanks for valuable comments to Francis Kramarz and Éric Maurin at CREST-INSEE in Paris, and, most of all, to Jeffrey Bergstrand. 
Gravity models provide ample evidence that a common language has a significant impact on bilateral trade. In the typical tests, the flow of bilateral trade between two countries is the dependent variable, and the explanatory variables include the respective output levels of the two countries. These variables also usually include some indicators of barriers or aids to trade, including prominently geographical distance. When a dummy variable for language is added, and it is scored as one in case of a common language and zero otherwise, the variable is generally highly significant. (For bibliography and examples, see Frankel (1997); Frankel and Rose (2002) offer fresh results.) Yet even if a common language thus clearly helps foreign trade, numerous questions remain. The previous dummy variable is itself a point of interrogation. This variable is often scored as one for a pair of countries when a minority of the population in one can understand the people in the other (sometimes less than $5 \%$, as in the instance of Niger-Burkina Faso or Pakistan-Tanzania). But it is scored the same way if over $95 \%$ of the population in both places can communicate directly (Germany-Austria). The implication is that the actual number of people who can communicate directly does not matter: if only some other criteria are met, a small proportion of bilingual individuals can make the desired market information available to everyone. In other words, an adequate system of translation will do just as well as direct communication in fostering foreign trade. But is this true?

Other basic questions abound. Is the world's dominant language, English, more effective than the rest in promoting trade? Does a common language boost trade between some countries at the expense of others or increase trade in general? Are the frequent references to the network externalities of a common language correct? Further still, how important is a common language inside a country? Does linguistic diversity at home reduce domestic trade? If so, is there compensation through foreign trade? Last but not least, does literacy promote trade? This whole host of questions about language and trade forms the subject of this inquiry.

Our typical use of binary variables in economics as indicators of a common language largely reflects the difficulty of quantifying the numbers of speakers of different languages in a country. But some headway is possible. Perhaps the most extensive basis for progress today is Grimes (2000), now in its $14^{\text {th }}$ edition since first appearing in 1951. This work is a massive effort to condense the information supplied by the entire profession of ethnologists about 
world languages. There have been at least three recent efforts to use this work to construct a general quantitative index of language in economic research: Hall and Jones (1999), Wagner (2000) and Rauch and Trindade (2002). I shall do the same but with a somewhat different purpose: that of providing a general index of the ability to communicate directly in worldwide trade. Hall and Jones do not center on communication and limit their attention to a few major languages. Wagner, though concerned with communication, deals strictly with bilateral trade with Canadian provinces, and chooses his languages accordingly. For their part, Rauch and Trindade collect data strictly on common native languages, whereas, of course, bilingualism is central with respect to communication. There had been one earlier effort to construct a general quantitative index of a common language, by Boisso and Ferrantino (1997). But in this pioneering work, the authors proceeded, like Rauch and Trindade, to attribute only a single language to each person, and they also relied on a far more summary treatment than Grimes', by Katzner (1986).

As an added interest, the latest edition of Grimes (2000) contains an index of linguistic diversity for all countries present in the study for the first time. The index concerns "the probability that any two people in the country picked at random will have different mother tongues" (Grimes (2000), p. x). The higher the index - the closer to one - the higher the probability that a random pair of individuals will have different mother tongues (see Lieberson (1981)). It would have served me better to have an index of the probability that any two people at random in a country will not be able to communicate through a common language, since two people with different mother tongues may evidently both be fluent in a third language. But the linguistic diversity index in Grimes can serve as a reflection of my preferred one. Mauro (1995) uses a similar index: namely, Taylor and Hudson's (1972) index of ethnolinguistic fractionalization (which derives entirely from a detailed Soviet linguistic study dating 1964). Despite the sociological emphasis of the title, "ethnolinguistic fractionalization," Taylor and Hudson's index pertains to the identical issue whether two randomly chosen individuals in a country will share the same maternal language. Since Mauro (1995), Alesina and Wacziag (1998), Easterly and Levine (1997) and La Porta et al. (1999) have also exploited the Taylor-Hudson index. However, these authors use the Taylor-Hudson index to treat issues of 
societal division and government behavior, ${ }^{1}$ while I shall use the Grimes index strictly in connection with communication. In regard to the 108 "countries" which both Grimes and TaylorHudson score for linguistic diversity, the correlation coefficient between the two indices is .85 .

The basic results can be summarized as follows. First, a common language promotes international trade both directly and via translation, that is, both as a result of sheer numbers who can communicate person to person, and as a result of an established network of translation. One cannot say whether direct communication or a network of translation is more important. Second, a common language increases foreign trade in the aggregate. There is some substitution: that is, an increase in foreign trade between two sets of nationals who share a common language (directly or through translation) does come at the expense of trade with different foreigners; but the overall effect on foreign trade is positive. Third, a common language exerts positive network externalities on foreign trade. But these externalities issue from within the trading countries themselves. There is no evidence that the broad usage of a language elsewhere affects bilateral trade between two countries. Thus, despite the dominant position of English as a world language, English is no more effective in promoting trade than other major European languages. Still, as a fourth basic conclusion, the major European languages as a group (including English) are more efficient than other languages in promoting trade. Fifth, a diversity of tongues at home does indeed boost foreign trade, and therefore, if only by implication, diminishes domestic trade. Sixth and last, literacy increases foreign trade. Indeed, literacy emerges as by far the most important linguistic influence in the study (with Student $t$ s of around 20). As an indication, the impact of a one-percent increase in literacy on foreign trade compensates for as much as a three-percent drop in language diversity inside a country.

The discussion will begin by developing the specific gravity equation that will serve in the empirical analysis (Section I). Next, I will explain my two indices of a common language, the one relating to direct communication and the other concerning translation. Section III will

\footnotetext{
1 This practice has aroused criticism from Collier (2001). Easterly and Levine (1997) provide some detailed discussion of the Taylor-Hudson index (derived from the Soviet study) and other closely related indices (which they have used and La Porta et al. have followed in doing).
} 
present the elementary econometric results. Section IV will then extend the analysis to three specific issues: first, the effects of different languages; second, the distinction between the scale (trade-creation) and the substitution (trade-diversion) effects of a common language; and third, the contribution of network externalities of language to bilateral trade. The final section will contain some general discussion and suggestions for future research. All the raw linguistic series, including those I constructed, are in the data appendix.

\section{The gravity model}

The gravity model is particularly fitting here because it focuses on the general barriers to trade, apart from the linguistic ones. Without controlling for other obstacles and aids to trade besides language - distance, political association, ex-colonial relationships, and the rest - it would be difficult, if not impossible, to draw inferences about linguistic effects, as such.

In using the gravity model, I shall limit attention to influences on total bilateral trade, without regard to differences between exports and imports. This opens the way for an important simplifying assumption: namely, that trade frictions raise the price to the importer above the exporter's price by the same percentage, regardless whether the goods move one way or the other. On that supposition, if we accept the usual assumptions of gravity models that all countries specialize in the production of a separate good, and that utility functions are identical, homothetic, and CES everywhere, balanced trade results. There is then nothing except aggregate trade to investigate. With trade costs the same regardless which way goods move, Anderson and van Wincoop (2001) show that a particularly simple form of the gravity equation follows. It is:

$$
\text { (1) } T_{i j}=\frac{Y_{i} Y_{j}}{Y^{W}}\left(\frac{t_{i j}}{P_{i} P_{j}}\right)^{1-\sigma}
$$

where $T_{i j}$ is the trade flow in either direction between countries $i$ and $j, Y_{i}$ and $Y_{j}$ are the respective incomes of the two countries, $\mathrm{Y}^{\mathrm{W}}$ is world income, $\sigma$ is the elasticity of substitution between different goods, $\mathrm{t}_{\mathrm{ij}}$ is $1+\mathrm{x}_{\mathrm{ij}}$ with $\mathrm{x}_{\mathrm{ij}}$ standing for the percentage of the costs attributable to trade frictions in relation to the export price $\mathrm{p}$ (regardless whether this price (fob) is $\mathrm{p}_{\mathrm{i}}$ or $\mathrm{p}_{\mathrm{j}}$ ), and $\mathrm{P}_{\mathrm{i}}$ and $\mathrm{P}_{\mathrm{j}}$ are the respective Dixit-Stiglitz consumer-based price levels in the two countries. To take the case of $\mathrm{P}_{\mathrm{j}}$ : 


$$
\text { (2) } P_{j}=\left[\sum_{i}\left(\beta_{i} p_{i} t_{i j}\right)^{1-\sigma}\right]^{1 /(1-\sigma)}
$$

where the summation sign embraces all i prices inclusive of $p_{j}$, and $\beta_{i}$ is the distribution parameter of the utility function (and the corresponding equation holds for $\mathrm{P}_{\mathrm{i}}$ ). Evidently, $\sigma$ must be greater than one, as empirical work tells us is overwhelmingly the case, if there is to be a negative effect of $t_{i j}$ on trade.

Distribution costs can be easily incorporated in the preceding model, and this is important since language plainly affects trade partly by modifying costs of distribution. As Baier and Bergstrand (2001) recently show (in line with Bergstrand (1985)), injecting distribution costs is no problem: it merely requires supposing that a CES relationship applies to the "transformation" of goods into sales between different national markets. So long as the elasticity of "transformation" is the same whether goods move one way or the other, the gravity equation retains the same structural form as equation (1). The only differences are that the parenthetical expression $\left(\mathrm{t}_{\mathrm{ij}} / \mathrm{P}_{\mathrm{i}} \mathrm{P}_{\mathrm{j}}\right)$ in this equation will comprise more terms and the entire expression will be raised to the power $\gamma /(\gamma+\sigma)$ rather than $1-\sigma$, where $\gamma$ is the elasticity of transformation (see Baier and Bergstrand, sec. 2.3.4). From the standpoint of estimation, however, these differences are minor. ${ }^{2}$

One fundamental problem raised by estimation of equation (1) is the treatment of the theoretical price indices, $\mathrm{P}_{\mathrm{i}}$ and $\mathrm{P}_{\mathrm{j}}$. Perhaps the only simple way to handle the problem is to introduce a separate fixed effect for each individual country. Several authors have recently chosen this route, and Feenstra (2003, ch. 5) provides a lucid explanation of the justification for the choice. Yet country fixed-effects do bear one important inconvenience. They interfere with the use of other explanatory variables that are country-specific and constant over time, since those variables will be perfectly correlated with the country dummy. In my own case, the study is essentially cross-sectional. Therefore, the problem looms significant: in particular, using country fixed-effects would mean eliminating literacy and linguistic diversity, two of the basic linguistic variables in the analysis. As a result, I will estimate equation (1) in two forms:

\footnotetext{
2 Of course, Bergstrand himself has always favored a more complicated version with distinct export and import behavior in his considerable work on gravity models (including the paper with Baier).
} 
one without country fixed-effects where all the relevant gravity variables are present and another with country fixed-effects and no other country-specific variables on the right hand side.

Quite specifically, I shall construe the critical $t_{i j}$ term in equation (1) to be:

(3) $t_{i j}=\prod_{k=1}^{k=m} u_{k}^{\gamma} \times \exp \left(\sum_{k=1}^{k=n} \eta_{k} v_{k}\right)$

where the $u$ terms are continuous variables, and the $v$ ones are $0-1$ dummies. The two estimated forms of the gravity model will then be:

(4) $\log \mathrm{T}_{\mathrm{ij}}=$ constant $+\alpha \log \left(\mathrm{Y}_{\mathrm{i}} \mathrm{Y}_{\mathrm{j}}\right)+(1-\sigma) \gamma_{1} \log \mathrm{u}_{1} \ldots+(1-\sigma) \gamma_{\mathrm{m}} \log \mathrm{u}_{\mathrm{m}}$

$$
\begin{aligned}
& +(1-\sigma) \eta_{1} \mathrm{v}_{1}+\ldots+(1-\sigma) \eta_{\mathrm{n}} \mathrm{v}_{\mathrm{n}} \\
& +(1-\sigma) \lambda_{1} \log \mathrm{w}_{1}+(1-\sigma) \lambda_{\mathrm{r}} \log \mathrm{w}_{\mathrm{r}}+\mathrm{e}_{\mathrm{ij}}
\end{aligned}
$$

and

(5) $\log \mathrm{T}_{\mathrm{ij}}=$ constant $+(\sigma-1) \delta_{\mathrm{i}} \mathrm{C}_{\mathrm{i}}+(\sigma-1) \delta_{\mathrm{j}} \mathrm{C}_{\mathrm{j}}+(1-\sigma) \gamma_{1} \log \mathrm{u}_{1} \ldots+(1-\sigma) \gamma_{\underline{\mathrm{m}}} \log \mathrm{u}_{\underline{\mathrm{m}}}$

$$
\begin{aligned}
& +(1-\sigma) \eta_{1} \mathrm{v}_{1}+\ldots+(1-\sigma) \eta_{\underline{\underline{n}}} \mathrm{v}_{\underline{\underline{n}}} \\
& +(1-\sigma) \lambda_{1} \log \mathrm{w}_{1}+(1-\sigma) \lambda_{\underline{\underline{I}}} \log \mathrm{w}_{\underline{\underline{r}}}+\mathrm{e}_{\mathrm{ij}}
\end{aligned}
$$

Equation (4) is the form without country fixed-effects while equation (5) is the one that contains them. The constants in both equations refer to $\mathrm{Y}^{\mathrm{W}}$. The coefficient $\alpha$ of the $\log \left(\mathrm{Y}_{\mathrm{i}} \mathrm{Y}_{\mathrm{j}}\right)$ term in equation (4) should evidently equal one. This coefficient is absent from equation (5). $\mathrm{C}_{\mathrm{i}}$ and $\mathrm{C}_{\mathrm{j}}$ in equation (5) are the dummies standing for countries $\mathrm{i}$ and $\mathrm{j}$ in observation $\mathrm{T}_{\mathrm{ij}}$ and are equal one. There are also separate country dummies for all the countries in the study in the equation; but the rest all equal zero and have been suppressed. The $\underline{m}$ members of $u_{\mathrm{k}}$ in equation (5) then refer to those of the $u_{k}$ variables in equation (4) that are not defined by country but instead by country pair $(\underline{\mathrm{m}} \leq \mathrm{m})$ while the $\underline{\mathrm{n}}$ members of $\mathrm{v}_{\underline{\mathrm{k}}}$ in equation $(5)$ are the corresponding $v_{k}$ variables in equation $(4)(\underline{n} \leq n)$. The new $w_{k}$ terms $(\underline{r} \leq r)$ refer to possible influences on balanced-bilateral-trade that are consistent with the assumptions of the model but are not reflected in any other way. A fitting example of $w_{k}$ would be differences in climate. If large differences in climate between country pairs imply better opportunities for trade between them than with other countries that have more similar climates, the variable should be added. It would not be reflected otherwise - in consumer tastes, general price levels, or trade frictions - but would be consistent with balanced trade. On the other hand, the exchange rate would be 
ineligible as a $\mathrm{w}_{\mathrm{k}}$ term, since this variable necessarily has opposite implications for two trading partners. The term $\mathrm{e}_{\mathrm{ij}}$ is white noise associated with the dependent variable, bilateral trade. The bulk of the discussion will relate to equation (4), while the test of equation (5) will serve essentially as a check.

Apart from the language variables, the precise $\mathrm{u}, \mathrm{v}$ and $\mathrm{w}$ terms in the estimates will be as follows. The asterisks designate those that drop out in passing from equation (4) to (5):

$\log \mathrm{u}_{1}, \ldots, \log \mathrm{u}_{\mathrm{m}}=\log$ of (product of) relative distance, $\log$ of (product of) remoteness*, $\log$ of (product of) population*, log of (product of) land area*.

$\mathrm{v}_{1}, \ldots, \mathrm{v}_{\mathrm{n}}=$ adjacency, number of landlocked in pair*, currency union, political union, free trade area, ex-colonial relationship, ex-common colonizer.

$\log \mathrm{w}_{1}=$ North-South difference.

The first two $\mathrm{u}$ variables decompose bilateral distance into the distance divided by remoteness (more exactly, the distance squared divided by the remoteness of one trading partner times that of the other), and remoteness itself. The remoteness of a particular country is the straight-line average of the distances of the country from all the others in the sample. This decomposition permits a separate estimate of the effect of distance in shifting trade away from more distant foreign trade partners toward closer ones, and between all foreigners and fellow countrymen. ${ }^{3}$ Frankel and Romer (1999) provide a particularly cogent explanation for the next two variables, population and land area. As they observe, the two reflect the negative pull of domestic trade on foreign trade. The more people there are at home, the wider the opportunities to trade domestically, and therefore without bearing the costs of foreign trade. Land area, in turn, is an indicator of internal distance (which has sometimes been measured, perhaps

\footnotetext{
${ }^{3}$ Note that my definition of remoteness differs from the typical one in referring strictly to geography. Remoteness is generally not conceived as a pure geographical variable at all, but a reflection of the opposite pull of third countries on the trade of a specific country with a specific trade partner. The weakness of this opposite pull is taken to be measured by the sum of the weighted distances of the country in question with third countries, where the weights are third-country outputs. According to this conception, remoteness is a relative term: Australia's remoteness is higher in trade with New Zealand than with the United States. (See, for example, Helliwell (1998), who has taken more recently to using the more felicitous term, "alternative trade opportunities," ALT, for the inverse of remoteness (Helliwell and Verdier (2001)). In my parlance, Australia is remote, period. In addition, its remoteness reduces its trade with all foreigners in favor of domestic trade.
} 
more intuitively, as a line between two domestic locations, as in Wei (1996)). Imagine the hypothetical enlargement of a country at a given population size. As the country grows, the distances separating the country from foreigners - in some directions at least - must rise. Therefore, domestic trade should benefit at the expense of foreign trade.

The $\mathrm{v}$ variables assume the values of zero or one, except for the number of landlocked in a pair, which can be two. Adjacency and the number of landlocked evidently relate to transport and distance generally. The last four $\mathrm{v}$ variables are indices of political association that Frankel and Rose have successfully used. The concern with ex-colonial relationships and an ex-common colonizer is particularly important, since former colonial attachments have strong linguistic consequences, and if colonial variables were left out of the analysis, any significance of language could be attributed to earlier colonial attachments. The dummy variables for the political associations also provide some reflection of protectionism, which is not otherwise taken into account. There exist detailed indices of trade protection, but these apply to a much narrower sample of countries. The only w variable in the study is the North-South difference between trading partners, as measured by the absolute difference in the latitudes of the two. ${ }^{4}$ The idea is that a country's latitude affects the length of its days, its sunlight, its temperatures and seasons, and thus will alter not only its plant and animal life and the yield of its lands and waters, but also its required insulation, energy and equipment, and its optimal production techniques. As I have argued before (Melitz (2001)), the North-South difference may therefore foster trade based on comparative advantage.

The next section turns to the principal concern, language.

\section{The language variables}

The meaning of a common language between two countries ceases to be obvious once we admit translation. In principle, a small group of bilinguals could make all market information available to each person in his or her preferred tongue in both countries. This could be

\footnotetext{
${ }^{4}$ Let lat 1 and lat 2 stand for the respective latitudes of country 1 and country 2 in a trading pair (with Northern latitudes positive and Southern ones negative). Then the North-South difference is |lat1 - lat2|. A related variable that has now become popular in studies of economic growth is Distance from the Tropics, |lat1 $|+|$ lat2|. But the variable proves insignificant in my tests regarding trade.
} 
done on-line via an electronic system. Or alternatively, one could imagine wholesalers employing translators to provide all market information to everyone further down the distribution chain in their own language. In either case, the marginal cost of the translation services could be zero to the final users. This last condition is essential. To see why, consider the analogy with money. National currencies can also be converted through banks. But the purchaser of foreign currency pays the exchange cost in every transaction. If it were necessary to pay for the translation of every separate message in a foreign tongue, there would be no question of a common language. But if new foreign-language messages can be gotten in one's home tongue for free, then the linguistic barrier may be non-existent or weak. As I have indicated before, the usual treatment of a common language as an all-or-nothing condition suggests that translation is a free good at the margin.

Indeed, it is possible to turn the whole issue of a common language on its head, and to ask how there can possibly be any language barrier if translation can link up all world languages to one another. There are two obvious answers; but while their joint significance is clear, their relative importance is not. The first regards the costs of translation - the social overhead costs of enabling the broad distribution of translation services as well as the costs of dealing out such services to people individually. Even if true, based on the previous paragraph, that once an appropriate foundation for widespread translation has been laid, the services can be provided to individuals at a negligible cost, the social overhead costs can be very important, and the usual treatment of a common language in foreign trade says that they are. According to this treatment, the problems of mounting and maintaining a language network are so large that, regardless of population size and number of languages, only two common languages exist between any pair of countries at most. The second answer to the query why language barriers are significant is the need for direct communication. Perhaps the clearest indication we have of the separate importance of direct communication in trade comes from applications of gravity models which show that immigrants increase trade with their country of origin (see Gould (1994), Head and Ries (1998), and Dunlevy and Hutchinson (1999), Wagner, Head and Ries (2002), and Rauch and Trindade (2001)). One reason for this effect may well be the immigrants' ability to speak their native language (as well as their capacity to 
translate the language into the primary one(s) in the host country). Accordingly, I will develop separate measures of a common language pertaining to a communication network and direct communication. In doing so, I will use only one supplementary source besides Grimes (2000): the CIA country factbook - a frequent reference among economists. My decision to stick to Grimes and the CIA factbook, following a broader search, is largely aimed to facilitate reproduction.

The first measure, titled "open-circuit communication," will require no set number of speakers for a common language, but simply demand that the language be either official or widely spoken in both countries (in any combination). By "widely spoken," I will mean that 20 percent or more of the population possesses the language..$^{5}$ In accordance with previous work, I will also recognize only two "open-circuit" languages at most in any country. Seldom will this last limitation make any difference, and where it does, I will retain the two languages with the widest international currency. This will essentially mean sticking to Arabic, English and French in some African examples where one or another of these languages could have been dropped in favor of Swahili, Hausa or Fulfulde, as the case may be. Open-circuit Communication has a value of one if the required condition is met (in any combination of the two branches) and zero otherwise. It cannot be overemphasized that this measure results from an effort to make sense of the indices of a common language that have served thus far. Fifteen open-circuit languages result from the criterion; all are listed in Table 1.

The second measure, "direct communication," depends on the percentage of speakers in both countries. Fortunately, those percentages needed to be calculated only when they were large enough to make any statistical difference in the analysis, or in explaining bilateral trade. I eventually retained $4 \%$ as the minimum figure for a language to count for Direct Communication. This limited the number of relevant languages to 29 out of the total of over 5,000 in the 185 "countries" in the study (including some overseas departments and territories). Lowering the required percentage to 3 would have increased the relevant number of languages by a

\footnotetext{
${ }^{5}$ Any figure in the $10 \%$ to $30 \%$ range would have made only modest difference, in light of the importance of official status. de Swaan (2000) contains some interesting discussion of the frequent assignment of official status to a minority language in multilingual societies.
} 
dozen or so without affecting the estimates perceptibly. In constructing the figures, I treated different dialects, creole and pidgin versions of a language as equivalent. I also deliberately cumulated speakers of a language without regard to any other languages they may possess. ${ }^{6}$ Where numbers of speakers could not be inferred from Grimes in any other way, I used literacy as a guide, while paying attention to the alternative language(s) to which the literacy rates might refer. In those instances, the CIA country factbook came into significant play, since I relied on this source for the literacy rates, and only used Grimes to fill in missing values. (My reason for switching to the factbook for literacy rates lies in the much wider discrepancies in the dating of the variable in Grimes.) The figure for Direct Communication obtains by summing up the products of the respective percentages of speakers over all the relevant languages (at least 4\%) in the two trading countries. In principle, those values could have exceeded one because of bilingualism. But very few such cases arose. In those cases, I set the numbers equal to one, which was equivalent to a general normalization.

The underlying hypotheses about the impact of the language variables in the study are fairly obvious. Different languages are impediments to communication, therefore trade. There is also more uniformity of language within a country than between a country and the rest of the world, and linguistic obstacles must especially interfere with foreign trade. It follows that higher levels of Open-circuit and Direct Communication should both raise foreign trade. In addition, linguistic diversity at home should do the same since it reduces the ability to skirt linguistic barriers through domestic trade. Finally, linguistic obstacles must be more severe for people who cannot read and write. Therefore, those people will be particularly handicapped in foreign trade. Thus, literacy should promote foreign trade.

Table 1 lists all 29 languages figuring in the Direct Communication index and shows all 15 of those that also serve as open-circuit languages. In the case of Open-circuit Communication, the cited languages are strictly "source" languages. The "destination" languages -

\footnotetext{
${ }^{6}$ Hutchinson (2002) recently tested the difference between English as a first language and as a second language (based on data in Crystal (1997)) using a gravity specification. He dealt exclusively with bilateral trade with the United States. Interestingly, English as a second language emerged, if anything, as more significant. However, judging from the results, the distinction between English as a first or a second language would fail any statistical test.
} 
those in which the messages are received - constitute a large number, probably over a hundred, which remains undetermined here. (There are about 250 languages in the world with over a million speakers, and some small languages, like Maltese, receive strong government support.) It is noteworthy that a few of the 15 open-circuit languages are small, whereas many big languages are missing from the 29 direct-communication ones. Big languages may be missing because of strict importance in domestic trade. Japanese is an example. They could also be missing because of lack of trade data. Striking examples come from the ex-Soviet Union and they include Russian.

The appendix contains my scoring of the linguistic information underlying the construction of the language variables. There, I also display the assignment of languages by country by Frankel and Rose (2002), whose database I use for other variables besides language. The latter assignment follows corrections for a few slips in the working paper version of the article which happened to catch my attention in an earlier study (Melitz (2001)) (most of which Frankel and Rose have since repaired). Table 2 shows the correlation matrix relating to my two indices of a common language and their single one over the (approximately) 30,000 observations of bilateral trade in the statistical analysis. The indices of literacy and language diversity in the study are also included in the correlation matrix. As can be seen, the correlation between Open-circuit Communication and Frankel and Rose's (FR) Common Language is only .81 - rather low if we consider that the two are probably meant to signify the same thing. This imperfect correlation stems entirely from my more frequent assignment of "opencircuit" languages to countries than theirs (with the single exception of Mauritania, which they list as French-speaking and I do not). In the first place, there are six open-circuit languages in my work that FR do not recognize at all: Danish, Greek, Turkish, Persian, Hindi and Malay. In addition, I assign the other nine open-circuit languages many more times than they do (for example, Spanish in Gibraltar, Dutch in the Dutch Antilles, English in St. Helena, French in Algeria, Morocco and Tunisia, etc.). Also noteworthy is the fact that the correlation coefficient between my two language indices, Open-circuit and Direct Communication, is high, 0.73, but not so high as to undermine the distinction - especially when we consider that both indices are zero in nearly three-quarters of the cases. 
Table 2 further displays the lack of any correlation of my two indices of linguistic ties with literacy and linguistic diversity. But unsurprisingly, these last two variables are significantly negatively correlated with one another (-.43). We would expect so since a large number of major languages in a country will often be a sign of low levels of market integration (not always, if only because of immigration). Consequently, such survival tends to go together with poverty and illiteracy.

\section{The basic results}

Virtually all of the data for the variables besides language in the study come from Frankel and Rose (2002) and are described in their data appendix. I owe an enormous debt to Rose for making this data public on his website. There are only two changes here in the relevant Rose database (apart from the aforementioned corrections concerning language). First, I measure geographical distance differently. Whereas he locates countries at their geographical center (in conformity with the CIA), I place them wherever their most populous city stands (as found in the CD-Rom encarta). Second, I consider all departments and territories of a country as automatically belonging to a free trade zone in the mother country. As a result, my dummies for a common country and free trade area are mutually exclusive.

The first column of Table 3 shows the result of the test of equation (4) in the usual form, with (the log of) bilateral trade (nominal imports plus exports in dollars deflated by the U.S. GDP chain price index and divided by two) as the dependent variable. As in Frankel and Rose, the test covers observations for six separate years at five-year intervals, starting with 1970 and ending in 1995, and therefore includes controls for the individual years. Robust standard errors are shown (after correction for clustering of data for individual trading pairs). All of the earlier hypotheses are confirmed. The results are basically the same as those reported in Melitz (2001), which in turn do not differ from Frankel and Rose (2002) as regards the common variables in both studies (that is, all of them except the decomposition of distance between relative distance and remoteness, North-South, and the language variables). The rest of the discussion focuses on language.

First and foremost, all four linguistic variables enter significantly with the right positive signs. Of the four, the outstanding influence is the diversity of languages at home. But all 
other three linguistic variables have Student $t$ s above 3. The next two columns probe more deeply into the influences of Open-circuit and Direct Communication. These two influences partly overlap, and there could be some negative interaction between them. In order to see, I replaced them by their average - their sum divided by two - in column 2, and I termed this average "Common Language" (a variable of the same dimension as either one of them alone). The coefficient of Common Language shows up as essentially the sum of the two separate influences. On this evidence, the two influences bear distinct, additive impacts. Column 3 injects the FR index of a common language into the equation, and thereby focuses on the relative merits of FR's linguistic variable as opposed to my two. The FR index is totally unimportant. Its presence does not even alter the estimates and Student $t$ s of Open-circuit and Direct Communication. I experimented with the FR index in combination with either one of my two linguistic variables alone or their straight-line average. Either one of them totally dominates the FR index, with Student $t$ s more than twice as high, and the use of the average, Common Language, completely removes any significance of the FR index. To all evidence, the systematic and separate measurement of Open-circuit and Direct Communication is worthwhile, and facility of translation and direct intercourse represent distinct influences on foreign trade.

There is one unsatisfactory feature of the previous tests, however: the 1.4 outputelasticity of trade instead of one. This coefficient is impossible to interpret independently of the negative coefficient of population in the equation, since output and population are closely correlated (compare Frankel (1997, pp. 57-61)). But, at least on my interpretation, theoretically the two influences are distinct. One concerns the feature of homothetic preferences, whereas the other reflects the opportunities to trade at home and free of any of the obstacles to foreign trade. In addition, joint output is not really independent of bilateral trade, and most important of all at present, literacy interacts with per capita output (not surprisingly, in light of the influence of literacy on output: see, for example, Barro (1991)). If we regress (the log of) joint output $\left(\mathrm{Y}_{\mathrm{i}} \mathrm{Y}_{\mathrm{j}}\right)$ on (the $\log$ of) bilateral trade, (the log of) joint population, and joint literacy, control for individual years, and correct the standard errors for clustering, we get the following estimate: 
$\mathrm{Y}_{\mathrm{i}} \mathrm{Y}_{\mathrm{j}}=.19$ bilateral trade +.84 product of populations +2.76 product of literacy rates

$\begin{array}{llc}(.01) & (.002) & (0.03) \\ \mathrm{R}^{2}=.98 & \mathrm{n}=31249 & \text { number of clusters }=8202\end{array}$

(robust standard errors in parentheses). Evidently, therefore, it is impossible to distinguish the respective impacts of output, population and literacy on bilateral trade in the previous equations.

The next two estimates of equation (4) impose a unitary elasticity of influence of joint output on trade. ${ }^{7}$ The variable on the left hand side is then the ratio of bilateral trade to the product of the two countries' outputs. Column 4 replicates the estimate in column 1 following this change. The R-square jumps up from 65 to 89 percent. The product of the two countries' populations remains significant while its negative coefficient drops. However, this negative coefficient now can be properly interpreted, for the first time, as reflecting the impact of opportunities to trade with fellow citizens in diminishing foreign trade. The influence of remoteness also rises and becomes roughly equivalent to that of relative distance, though the coefficient of relative distance is still estimated far more precisely. (I have no explanation for this last alteration.) However, the most notable changes of all relate to the four linguistic variables. Those variables retain their signs and significance, but the impact of literacy shoots up. The most powerful linguistic influence on foreign trade in the study - by far - now emerges as the ability to read and write. According to the estimates, if we compare percentage-point for percentage-point, much more can be done to increase trade between two countries by promoting literacy than a common language. Of course, this effect of literacy could stem partly from production skills as well as the ability to communicate, especially since output is no longer present as an explanatory variable. Still, either way literacy is essential. More troubling would be any associated changes in tastes and income elasticities of demand, as these would conflict with my basic assumptions. I cannot explore the issue here: doing so would evidently require a more flexible version of the gravity model.

The last column of Table 3 facilitates interpretation of the relative influence of the other linguistic variables besides literacy. Once again, I substitute Common Language for Open-circuit and Direct Communication. Once more, this single variable has a coefficient that

\footnotetext{
${ }^{7}$ Compare Harrigan (1994) and Frankel and Rose (1998).
} 
matches the sum of the coefficients of the previous two. But the impact of Common Language now emerges as, if anything, higher than that of linguistic diversity. Its statistical significance is higher too. Thus, common linguistic ground with foreigners seems to be at least as important as linguistic diversity at home in fostering foreign trade. This is not necessarily surprising. Linguistic diversity encourages trade with all foreigners indiscriminately, whereas a common tongue promotes trade with those foreigners with whom communication is especially easy. From this perspective, the surprising thing may be that Common Language does not dominate language diversity even more.

\section{Further Tests}

\section{(a) Different languages}

Such is the supremacy of English as a world language today that there is cause to inquire whether English is more effective in promoting trade than other languages. It is difficult to see how English could be able to convey information better than other languages in personto-person communication - that is, except through external effects, which I will consider separately. But in the case of open-circuit communication, the greater effectiveness of English could come from economies of scale in the diffusion of messages, independently of any externalities. The question thus arises whether English exerts a greater influence as a source language on trade than the other open-circuit languages do.

I begin in Table 4 by repeating the estimate in column 4 of the previous table for convenience. The second column shows the result of the extreme assumption that English provides the only effective circuit of communication, or, in other words, that the other languages only affect trade through person-to-person communication. The general fit of the equation worsens somewhat and both the coefficient and the significance of Direct Communication rise. The third column is even more to the point: it shows what happens when we introduce Open-circuit Communication in English as a separate variable side by side with Open-circuit Communication. The latter emerges as the larger and more significant influence of the two. In addition, the difference between the two is patently not statistically significant. Hence, there is no evidence that English bears any impact on trade beyond its heavy contribution to Open- 
circuit and Direct Communication. ${ }^{8}$ I experimented next with English, Spanish, and French or the three most important languages in the study - as the only languages providing an effective circuit of communication. The results do not justify the conjecture. On the other hand, the idea that the European languages as a group are the only ones to serve as source languages in trade does receive notable support. Column 4 shows the outcome of the experiment (which excludes Arabic, Chinese, Hindi, Malay, Persian and Turkish from Open-circuit Communication). The estimate clearly improves, and this last improvement holds up in all my subsequent experiments. I will therefore only report further results with Open-circuit Communication in the European languages, and in summarizing, I will use a straight-line average of this Opencircuit variable and Direct Communication, termed Common Language*. The estimate of column 1 with Common Language* instead of Common Language is shown in column 5.

\section{(b) Substitution or scale effects}

Does a linguistic tie raise trade between two countries at the expense of trade with third countries or increase foreign trade in the aggregate? This sort of question has arisen before in connection with some of the other variables in the analysis: namely, the political associations: free trade agreement, currency union, and so forth. The basic approach has been to introduce a dummy variable for bilateral trade between two countries if one or both of them belong to the relevant political association with a third country but not with one another. The sign and statistical significance of the dummy variable tells us whether a substitution or a scale effect is present or whether neither one nor the other is true. However, this method cannot serve here - at least, not without modification. There are too few cases of bilateral trade between countries where neither one scores positively for Common Language* with anyone. As a result, any dummy of the previous sort, if used together with Common Language*, would

\footnotetext{
${ }^{8}$ Helliwell (1999) gets seemingly conflicting results. He finds English to be far more important than German, French or Spanish in a related study which treats a common language as a binary variable (explicitly based on status as an official language). But the conflict is not clear since our tests differ. Mine uses Direct Communication as a control variable, and English is eminently present in this variable. That is, I test for the separate significance of English as an Open-circuit Communication language. In addition, Helliwell's sample covers a much narrower group of countries, only 33, 22 of them from the OECD. As he notes himself, in a similar study as his using 63 countries, Frankel, Stein and Wei (1998) report no difference in the significance of English as opposed to Spanish, French or German.
} 
cover too much of the field (in cases where one is zero, the other is predominantly positive, and inversely). It would then prove impossible to distinguish statistically between the influences of the two. But a certain adaptation is possible.

Common Language* varies between values of 0 and 1 with disproportionately few examples of values between .1 and .5 , since any pair of countries scoring 1 for Open-circuit Communication in a European language must register at least .5 for Common Language*, and except for country pairs with a common open-circuit language in a non-European language, all others can score at most 0.1 for Common Language* (since they must score less than 0.2 for Direct Communication). It is then possible to construct an index of trade between country pairs that have a value below 1 for Common Language* where one but not the other member has a value of .1 or over for this variable in trade with some third country. This focuses attention on trade between countries that are generally "isolated" linguistically and countries that are predominantly not. As a result, there is still a large number of observations, constituting a sizable proportion of the sample, where both this indicator and Common Language* will be zero. These observations regard pairs of countries that both have some significant linguistic ties with someone but not with one another. The point of putting those cases aside is simply to make possible a test relating to the other, smaller, and distinct set of cases.

In instances where the previous specialized index of a linguistic barrier should be scored as positive, there is also a choice between scoring it 1 or the absolute difference between the two maximal values for Common Language* in trade with third parties. I experimented with both forms: the $0-1$ and the continuous varieties. Both forms yield identical results in the foregoing equations in Table 4. But if substitution or complementary effects are at issue, there is reason to ask whether currency unions, political unions, free trade agreements, and ex-colonial-relationships too yield substitution or complementary effects. This further exploration can be done in the usual manner: by scoring a dummy variable as 1 when a country member of a relevant political association trades with a country outside the association and 0 otherwise. Once those other dummy variables are added, the proposed 0-1 index for lack of linguistic ties drops substantially in significance while the continuous index (with positive values heavily concentrated in the 0.4-1 range) is much less affected. Therefore, I retained the 
continuous index.

The first column of Table 5 shows the outcome of the relevant experiment. The equation contains the relevant five new variables for trade with third parties, the one relating to a common language, and the four relating to the political associations. In the case of the political relationships, the results conform to earlier studies, and will receive no further comment (see Melitz (2001)). But in the case of language, our main concern, linguistic ties now appear to have a highly significant negative effect on trade with third parties. Still, this substitution effect is smaller than the positive effect of Common Language* on trade between countries with linguistic ties, and the difference between the two coefficients is very significant statistically (according to a Hausman test). Hence, there remains a net positive influence of linguistic ties on aggregate foreign trade (which could be entirely at the expense of domestic trade).

\section{(c) Network externalities}

What about the presence of "network externalities" of a common language? Advertisers pay more to publicize at peak times and in well-frequented places. It is entirely plausible that speakers of a language would benefit from larger numbers of other speakers of the same tongue in the market. Perhaps the outstanding formal development of the idea comes from Church and King (1993) (who wrote with the issue of French and English in Canada in mind). A related development is in Lazear (1999), whose presentation has the added interest of centering the external benefits precisely on trade (though he does not focus on externalities himself). Random encounters take place between people. If they speak the same language, a trade occurs. Otherwise, it doesn't. The more individuals in a surrounding that speak the same language, the higher the probability that random encounters will result in trades. It should be noted that both Church and King and Lazear consider the issue to be strictly direct communication, as is not the case here. Numerous passing references to network externalities of a common language can also be found in print. (One outstanding, oft-cited case is Sabourin (1985).) Interestingly, Dowd and Greenaway (1993) close an article on the network externalities of money with a paragraph suggesting the application of their reasoning to language. Yet I know of no previous attempt to test the hypothesis of external benefits of a common language. 
In trying to do so here, I will entertain two separate but complementary meanings (or manifestations) of external benefits of a common language. The first is intrinsic; the second is not but often intimated. Any network externality of a common language says that the impact of the language depends on the numbers of people who are connected (either directly or through a circuit) rather than merely the percentages. Thus, a given percentage of English speakers in a small community should have a smaller impact on the intensity of trade, or the ratio of trade to income, than the same percentage in a huge community if network externalities really matter. Beyond numbers, though, what must be relevant is the aggregate income of the people in a language circuit (or who are hooked up). Accordingly, my first measure of a source of external effects of a common language is the aggregate real income of the people with linguistic ties: that is, the product of the percentage value, Common Language*, and the sum of real incomes of the two trading countries combined (in logs). Since Common Language* is a constant in the study, I shall use a constant for real income as well, namely, the value for 1990, or in the few cases where only earlier figures are available (at five-year intervals), the latest one. ${ }^{9}$

My second, and more conjectural, measure relates to the external effects of a common language stemming from third-countries. The hypothesis in this case is that worldwide usage is important. A simple interpretation goes as follows: so far as people have a choice of language because they are bilingual (multilingual) or live in a country which receives messages in two open-circuit languages, they will tend to gravitate toward the one with the widest international currency - even if (as concerns Direct Communication) that language is not their preferred one and they do not master it well. Under this hypothesis, a language with widespread usage in the world may wield a larger impact on bilateral trade than another language that is better-known within the two countries. Evidently, this last sort of external effect on bilateral trade cannot be captured by any aggregate of income within the two countries.

Accordingly, I constructed a separate measure of income for the previous sort of external effects. In this case, nine languages drop out (including one of the open-circuit languages, Swedish, which strictly functions between Sweden and Finland). This leaves twenty. For

\footnotetext{
${ }^{9}$ I see no advantage in averaging the (one to six) annual figures for individual country pairs.
} 
every bilateral pair, a different total of these twenty world aggregates of income was constructed. An example will suffice. Consider a trading pair with a Common Language* of .8, composed of .5 for English, .2 for Arabic and .1 for a third language that does not operate elsewhere (or, effectively, is neither official nor spoken by as many as $4 \%$ of the population anywhere else). The construction of the index then begins with the separate totals for the world income of people who can receive messages sent in English and in Arabic, based on a previous calculation founded on the data in the language appendix and 1980 real income. ${ }^{10}$ The third language is simply ignored. Next, the respective contributions of the trading pair to the preceding English and Arabic income aggregates are deducted. Finally, a coefficient of .5 is applied to the remainder for English, one of .2 to the remainder for Arabic, and the two totals are added up. The log of this sum of world income serves in the estimates.

The results confirm the hypothesis of external effects coming from inside the trading countries but deny any similar external effects coming from the rest of the world. The confirmation of the external effects from within is shown in the second column of Table 5. Both the index of external effects and Common Language* can be seen to be significant at the $5 \%$ confidence level. The root mean square error also drops in this estimate. (Note that all 29 "source" languages function in this case.) In addition, the coefficient of Common Language* is lower than before. But this is only to be expected, since the impact of this variable now comes partly from a joint effect with income. The coefficient of Common Language* is also estimated with much less precision. This next deterioration cannot be ascribed to any confusion with the index of external effects, since Common Language* and this index are uncorrelated over the pertinent observations (namely, those where both variables are positive (as in the other examples both of them are zero by construction)). Thus, the drop in precision must be the result of lower statistical variance.

The index of external effects stemming from third countries is never significant except when used alone, that is, in the absence of Common Language* or the preceding index of ex-

\footnotetext{
${ }^{10}$ Regarding English, the earlier calculation goes as follows. For each country, one at a time, take one or zero depending upon whether English is an Open-circuit Language, add the figure for English under Spoken Languages, divide by two, and multiply by the country's 1990 income. Then add up all the country totals. Repeat for Arabic, etc.
} 
ternal influence. As shown in column 3 of Table 5, if this variable is merely added in the previous equation, Common Language* is the only one of the three that remains significant. The previous index of external effects also becomes unimportant. The fact that the new index of external influence is significant when included alone has no particular importance, but must be attributed to the index's positive correlation of .6 with Common Language* (over the relevant observations). ${ }^{11}$ There is independent reason to think so. If the external effects of language coming from third countries were significant, we might have expected English to show up as a separate influence on bilateral trade in the previous test without any control for external effects. Such was not the case. This reinforces the conclusion that the only externalities affecting trade are those coming from inside the borders of the trading parties themselves.

(d) Country-specific fixed effects

Finally, consider the result of testing equation (5) rather than equation (4), that is, in the case of fixed effects for all "countries" (185 fixed effects in all, 25 of which drop out). A new dummy variable for country $i$ and another for country $j$ then enter in explaining each trade observation, $\mathrm{T}_{\mathrm{ij}}$. Further, all the earlier variables that depend on country $\mathrm{i}$ or country $\mathrm{j}$ alone are removed. Those that drop out are: namely, remoteness, population, land area, landlocked, language diversity and literacy. The only reason why the influence of these last variables might still be possible to estimate at all is that there may be as many as 6 observations for individual country pairs at five-year intervals. (This opens up the possibility of different pairings at different dates, and different values for identical pairings.) However, in principle, the performance of the other variables - those whose values depend on a country's trade partner should be unaffected. Accordingly, I only retained the previous variables in the next test: namely, relative distance, North-South, adjacency, Open-circuit Communication, Direct

${ }^{11}$ It may be important to explain why this .6 correlation is not inconsistent with the absence of any correlation between the other index of external effects - those coming from within the trading pairs - and Common Language*. The world income of English speakers is many times greater than the world income of speakers of any other language. English also contributes heavily to Common Language*. This combination of factors underlies the .6 correlation. On the other hand, there are many cases of tiny English-speaking countries trading with one another, while the index of the effects within the trading pairs depends strictly on the income of the trading parties themselves. This explains the lack of any correlation of this next index of external effects with Common Language*. 
Communication, the political variables, and the indicators of substitution or complementarity. (I also dropped the indicators of external effects, which depend on income, another variable that is defined by individual country). The results are shown in the last column of Table 5 .

Except for the indices of substitution or complementarity and two of the political variables (namely, free trade agreement and a common ex-colonizer), none of the relevant coefficients or standard errors is notably affected. The significance of a common language even goes up. Specifically, while the coefficient and significance of Open-circuit Communication in a European tongue drop (though the Student $t$ remains above 3), the coefficient and significance of Direct Communication double. (When used instead of Open-circuit and Direct Communication, Common Language* has a coefficient of .91 and standard error of .07.) The only drawback in this next test is that the impact of a common language on third parties ceases to emerge. On the whole, the test is plainly confirmatory. If we compare the results of the test or the last column of Table 5 - with the earlier estimates, we find only a moderate increase in $\mathrm{R}^{2}$ and precision of estimate. Thus, it would seem that remoteness, population, land area, access to sea, language diversity and literacy capture many of the relevant features of countries that are covered by the country fixed effects. All in all, not only is the admission of country fixed effects essentially corroborative, but one could easily exaggerate the difference between equations (4) and (5) in terms of relevant national detail.

\section{Discussion and conclusion}

We knew beforehand that a common language promotes trade. This study introduces a number of influences of language that had gone unnoticed before, or at least had not been studied. Not only is direct communication important in surmounting linguistic obstacles, but so is translation. The results clearly show the significance of special provisions for receiving translations from one or more selected foreign languages. Though few people may speak Portuguese in a country, they may be "tuned" to the language all the same. Unless we allow for special facilities for obtaining information issuing from chosen source languages, we miss a good deal of the ease of communication through language in foreign trade. Moreover, judging from the results, dictionaries, pictures, signs, numbers, and minimum vocabularies, etc., matter too in overcoming linguistic barriers. As evidence, literacy makes an important contribu- 
tion. If people can read and write in any language, they can cope better with the problems posed by foreign languages in general. As further evidence, the incentive to overcome language barriers is a factor. If people face linguistic obstacles at home, they somehow manage to trade more with foreigners. In sum, knowing a foreigner's language is only one of the ways of dealing with linguistic hurdles in foreign trade, and no single measure can cover the topic. But all of the linguistic influences on trade speak to the importance of resolving linguistic problems in foreign markets.

The separate and distinct effects of Open-circuit and Direct Communication on trade may also reflect some specialization. The two channels of communication could operate largely in trade in different sorts of goods. Open-circuit Communication might be especially important in trade in homogeneous goods, where rudimentary communication may suffice, whereas Direct Communication may serve heavily in trade in heterogeneous goods, which may require more sophisticated intercourse. Rauch (1999) implicitly suggests a hypothesis of this sort. He argues that close personal relations between exporters and importers are not necessarily significant in trade of perfectly homogeneous goods, whereas close personal interaction between exporters and importers is required in trade in heterogeneous goods. Because of issues of information, "markets" suffice in one case, while private "networks" are necessary in the other. The hypothesis of the separate roles of Open-Circuit and Direct Communication in the two cases follows easily. ${ }^{12} 13$

12 It might even be postulated that for certain homogeneous goods, including crude oil and many primary products, the relevant information is so small and easy to get (in part or entirely, because of organized exchanges) that there are no language hurdles at all. Translation may resolve the communication problem altogether at no notable cost of any sort.

13 Interestingly, Rauch and Trindade (2001) do not apply my proposed hypothesis to two different uses of language in communication but to the distinction between a common language and an ethnic network. They reason that whereas an ethnic network should promote trade in differentiated goods more than in homogeneous ones, a common language should affect trade in all categories of goods the same way. Their example of an ethnic network is the Chinese diaspora across the world, and their measure of a common language is a common native language. Since Rauch and Trindade use a single index of a common language, their measure may well reflect both Open-circuit and Direct Communication. Consequently, there is no plain conflict between us. Nevertheless, their interpretation of a common mother tongue raises a dissonant note. According to them, this (continuous) variable essentially reflects common tastes. In my eyes, the measure remains at least as much a reflection of the ability to communicate (even apart from any reflection of Open-circuit Communication or facility of transla- 
A few other results of the study probe further into specific aspects of language. English seems to offer no particular advantage in foreign trade, but the European languages in toto do: they emerge as better instruments of Open-channel Communication than other languages. In addition, linguistic links between countries tend to boost their bilateral trade partly at the expense of trade with third countries, but not entirely. Finally, there is some evidence that network externalities of language contribute to trade between countries. But so far as this is true, the external benefits depend on the aggregate income of the particular trading pairs. In general, however, network externalities are not as central in trade as they are sometimes imagined to be, and the reason may have to do with the earlier point that a lot of market information gets transmitted in the absence of a common language. ${ }^{14}$

In closing, a few extensions of the study may be suggested for future work. Language has been interpreted here strictly as a tool of communication, even though it obviously reflects many aspects of culture as well. The reason for this narrow interpretation is that the only features of the language variables in the study that apply generally regard communication. Other associated features are not always present. In the case of Direct Communication, I have basically assured the primacy of communication by including second-language and non-native speakers. (In the case of Open-circuit Communication, assuring this primacy was never even an issue.) However, additional variables reflecting culture or ethnicity would clearly be helpful. Based on previous work, one cultural variable that comes to mind is the stock of immigrants. As the analysis now stands, immigrants are already present since they affect the index of linguistic diversity, if nothing else. But this index marks long-standing, sometimes ancestral, linguistic divisions inside national boundaries as well. The interest of a separate consideration of immigrants lies in disentangling the element of ethnic ties to other communities abroad (which affects tastes, skills, trust and information) and setting off this element from strict issues of communication. Following this step, the index of linguistic diversity would be

tion). I will return to the issue of interpreting the import of a common language in the text. ${ }^{14}$ It may be worth noting as well that a common language may be more important in production than in trade. To all indication, even varying shades in the ability to communicate directly matter a lot in the labor market. Empirical work uniformly shows a considerable impact of linguistic skill on wages: see McManus, Gould and Welch (1983), Chiswick and Miller (1995), and the references in a broad survey by Grin (1996). 
easier to assign to matters of communication as such. A separate treatment of immigrants would generally reinforce the idea that the linguistic variables relate strictly to communication (compare Rauch and Trindade (2001) and the discussion in note 13).

Another useful extension would be to study trade in goods that are especially connected to language, such as movies, television programs, books, and vocal music. In these cases, the world dominance of English and the production by the U.S. in particular, is notorious. Cultural products in English sell extremely well in many places where English is otherwise secondary in foreign as well as domestic trade. Broadly, how come English plays no special role in facilitating foreign trade but dominates the market for language-related products? ${ }^{15}$ Evidently, the question cannot be studied within the confines of the current version of the gravity model, which applies strictly to two-way trade. Rather, the investigation would require a more intricate version of the model, which distinguishes between exports and imports and is largely associated with Bergstrand (1985). ${ }^{16}$

Finally, my treatment of the language variables as fixed effects can be questioned. Literacy rates have risen substantially in the last fifty years. Migrations accelerated in the nineties in many parts of the world. Spanish is now significant in the U.S., Russian in Israel, etc. I have treated the data furnished in Grimes (2000) as roughly contemporaneous. In doing so, I have followed the practice in economics of treating all indicators of a common language and linguistic diversity in foreign trade as slow-moving variables that can be regarded as constants. ${ }^{17}$ Moreover, Grimes (2000) corroborates the previous practice by furnishing unique figures for linguistic variables, despite wide discrepancies in dating, when dates appear. Yet from the standpoint of trade analysis, there is little doubt that more coherent series for literacy, Opencircuit Communication and Direct Communication could be constructed from a broad variety of national sources. Something could be done, in the process, to show the evolutions of all

\footnotetext{
${ }^{15}$ For some of the data, and a limited effort to answer the question, see Melitz (2000).

16 It may be noted that Gould (1994), Head and Ries (1998), Dunlevy and Hutchinson (1999), Wagner, Head and Ries (2002) and Hutchinson (2002), who all distinguish between the influence of immigrant links on imports and exports, all rely on specifications related to Bergstrand's.

17 This description holds for studies of trade, not labor. Labor studies of the impact of linguistic skills on wages make prominent use of time series evidence (see the references in note 14).
} 
three variables. Apart from an improved ability to test earlier hypotheses, one outcome would be the opportunity to tackle the question of the relationship between linguistic changes and the increase in the number of countries in the post-World War II period, a basic topic that Alesina and Spolaore (1997) have effectively raised. 


\section{REFERENCES CITED}

Alesina, Alberto and Enrico Spolaore (1997). "On the number and size of nations," Quarterly Journal of Economics, 112, 1027-1056.

Alesina, Alberto and Romain Wacziarg (1998). "Openness, country size and government," Journal of Public Economics 69, 305-321.

Anderson, James and Eric van Wincoop (2001). "Gravity with gravitas: A solution to the border problem," NBER Working Paper 8079.

Baier, Scott and Jeffrey Bergstrand (2001). "The growth of world trade: tariffs, transport costs, and income similarity," Journal of International Economics, 53, 1-27.

Barro, Robert (1991). "Economic growth in a cross section of countries," Quarterly Journal of Economics, 106, 407-443.

Bergstrand, Jeffrey (1985). "The gravity equation in international trade: Some microeconomic foundations and empirical evidence," Review of Economics and Statistics, 71, 143-153.

Boisso, Dale and Michael Ferrantino (1997). "Economic distance, cultural distance, and openness in international trade: Empirical puzzles," Journal of Economic Integration, 12, 456-484.

Central Intelligence Agency Country Factbook, U.S. government printing office, available online.

Chiswick, Barry and Paul Miller (1995). "The endogeneity between language and earnings: International analyses," Journal of Labor Economics, 13, 246-248.

Church, Jeffrey and Ian King (1993). "Bilingualism and network externalities," Canadian Journal of Economics, 26, 337-345.

Collier, Paul (2001). "Implications of ethnic diversity," Economic Policy, 32, 127-166.

Crystal, David (1997). English as a Global Language, Cambridge University Press.

de Swaan, Abram (2001). Words of the World, Polity Press: Cambridge, UK.

Dowd, Kevin and David Greenaway (1993). "Currency competition, network externalities and switching costs: Towards an alternative view of optimum currency areas," Economic Journal, 103, 1180-1189. 
Dunlevy, James and William Hutchinson (1999). "The impact of immigration on American import trade in the late nineteenth and early twentieth centuries," Journal of Economic History, 59, 1043-1062.

Easterly, William and Ross Levine (1997). "Africa's growth tragedy: Policies and ethnic divisions," Quarterly Journal of Economics, 112, 1203-1250.

Feenstra, Robert (2003). Advanced International Trade: Theory and Evidence, Princeton University Press, chapter 5, forthcoming.

Frankel, Jeffrey (1997). Regional trading blocs in the world trading system, Institute for International Economics.

Frankel, Jeffrey and David Romer (1999). "Does trade cause growth?" American Economic Review, 89, 379-399.

Frankel, Jeffrey and Andrew Rose (1998). "The endogeneity of the optimum currency area criteria," Economic Journal, 108, 1009-1025.

Frankel, Jeffrey and Andrew Rose (2002). "An estimate of the effect of common currencies on trade and income," Quarterly Journal of Economics, 117, 437-466.

Frankel, Jeffrey, Ernesto Stein and Shang-Jin Wei, "Continental trading blocs: Are they natural or supernatural?" in Jeffrey Frankel, ed., The regionalization of the world economy, The University of Chicago Press, 91-113.

Gould, David (1994). "Immigrant links to the home country: Empirical implications for U.S. bilateral trade flows," Review of Economics and Statistics, 69, 301-316.

Grimes, Barbara, ed. (2000). Ethnologue: Languages of the world, Summer Institute of Linguistics, International Academic Bookstore, Dallas, Texas, $14^{\text {th }}$ ed.

Grin, François (1996). "The economics of language: survey, assessment, and prospects," International Journal of the Sociology of Language, 121, 17-44.

Hall, Robert and Charles Jones (1999). "Why do some countries produce so much more output per worker than others?" Quarterly Journal of Economics, 114, 83-116.

Harrigan, James (1994). "Scale economies and the volume of trade," Review of Economics and Statistics, 76, 321-328.

Head, Keith and John Ries (1998). "Immigration and trade creation: Econometric evidence 
from Canada," Canadian Journal of Economics, 31, 46-62.

Helliwell, John (1998). How Much Do National Borders Matter? Washington D.C.: Brookings Institution.

Helliwell, John (1999). "Language and Trade," in A. Breton, ed., Exploring the Economics of Language, Canadian Heritage.

Helliwell, John and Geneviève Verdier (2001). "Measuring international trade distances: A new method applied to estimate provincial border effects in Canada," Canadian Journal of Economics, 34, 1024-41.

Hutchinson, William (2002). "Does ease of communication increase trade? Commonality of language and bilateral trade," Scottish Journal of Political Economy, 49, 544-556.

Katzner, Kenneth (1986). Languages of the world, Routledge and Kegan Paul.

La Porta, Rafael, Florencio Lopez-de-Silanes, Andrei Schleifer and Robert Vishny (1999). "The quality of government," Journal of Law, Economics and Organization 15, 222279.

Lazear, Edward (1999). "Culture and language," Journal of Political Economy, 107, no.6, pt.2, S95-S125.

Lieberson, Stanley (1981). Language diversity and language contact, Stanford University Press.

Mauro, Paolo (1995). "Corruption and growth," Quarterly Journal of Economics, 110, 681712.

McManus, Walter, William Gould and Finis Welch (1983). "Earnings of Hispanic men: The role of English language proficiency," Journal of Labor Economics, 1, 101-130.

Melitz, Jacques (2000). "English-language dominance, literature and welfare," Working Paper, University of Strathclyde, Glasgow (earlier version, CEPR Discussion Paper 2055, 1999).

Melitz, Jacques (2001). "Geography, trade and currency union,” Working Paper, University of Strathclyde, Glasgow (earlier version, CEPR Working Paper 2987, 2001).

Rauch, James (1999). "Networks versus markets in international trade," Journal of International Economics, 48, 7-35. 
Rauch, James and Vitor Trindade (2001). "Ethnic Chinese networks in international trade," Review of Economics and Statistics, 84, 116-130.

Sabourin, Conrad (1985). "La théorie des environnements linguistiques," in François Vaillancourt, Économie et langue, Conseil de la langue française, Québec.

Taylor, Charles and Michael Hudson (1972). World handbook of political and social indicators, Yale University Press, 2d. ed..

Wagner, Don (2000). "Essays on the mobility of goods and people," Dissertation at the University of British Columbia, Canada.

Wagner, Don, Keith Head and John Ries (2002). "Immigration and the trade of provinces," Scottish Journal of Political Economy, 49, 507-525.

Wei, Shang-Jin (1996). "Intra-national versus international trade: How stubborn are nation states in globalization?" NBER Working Paper 5531. 
TABLE 1

\section{LANGUAGES}

\section{Open-Circuit Languages}

Arabic

Chinese

Danish

Dutch

English

French

German

Greek

Hindi

Malay

Persian (Farsi)

Portuguese

Spanish

Swedish

Turkish
Other Direct-Communication Languages

Albanian

Fang

Fulfulde

Hausa

Hungarian

Italian

Javanese

Lingala

Nepali

Pashto

Quechua

Swahili

Tamil

Urdu

TABLE 2

\section{CORRELATION MATRIX}

Open-circuit Direct Communi- Common Language Literacy Language Communication cation Frankel-Rose

Open-circuit 1

Direct

0.73

1

Frankel-Rose

0.81

0.75

1

Literacy

$-0.10$

0.10

$-0.03$

Diversity

0.14

$-0.08$

0.07

$-0.43$ 
TABLE 3: THE BASIC RESULTS

\begin{tabular}{|c|c|c|c|c|c|}
\hline REGRESSAND: & Lo: & bilate & rade & $\begin{array}{l}\text { Bilatera } \\
\text { product }\end{array}$ & \\
\hline $\begin{array}{l}\text { Log product of } \\
\text { relative distance }\end{array}$ & $\begin{array}{l}-.63 \\
(.02)\end{array}$ & $\begin{array}{l}-.63 \\
(.02)\end{array}$ & $\begin{array}{l}-.63 \\
(.02)\end{array}$ & $\begin{array}{l}-.6 \\
(.02)\end{array}$ & $\begin{array}{l}-.6 \\
(.02)\end{array}$ \\
\hline $\begin{array}{l}\text { Log product of } \\
\text { remoteness }\end{array}$ & $\begin{array}{l}-.15 \\
(.07)\end{array}$ & $\begin{array}{l}-.15 \\
(.07)\end{array}$ & $\begin{array}{l}-.15 \\
(.07)\end{array}$ & $\begin{array}{l}-.54 \\
(.08)\end{array}$ & $\begin{array}{l}-.55 \\
(.07)\end{array}$ \\
\hline $\begin{array}{l}\text { Log North-South } \\
\text { Difference }\end{array}$ & $\begin{array}{c}.26 \\
(.02)\end{array}$ & $\begin{array}{l}.26 \\
(.02)\end{array}$ & $\begin{array}{l}.26 \\
(.02)\end{array}$ & $\begin{array}{l}.25 \\
(.02)\end{array}$ & $\begin{array}{l}.25 \\
(.02)\end{array}$ \\
\hline $\begin{array}{l}\text { Log product of real } \\
\text { GDP }\end{array}$ & $\begin{array}{c}1.4 \\
(.02)\end{array}$ & $\begin{array}{c}1.4 \\
(.02)\end{array}$ & $\begin{array}{c}1.4 \\
(.02)\end{array}$ & & \\
\hline $\begin{array}{l}\text { Log product of } \\
\text { Population }\end{array}$ & $\begin{array}{l}-.44 \\
(.02)\end{array}$ & $\begin{array}{l}-.44 \\
(.02)\end{array}$ & $\begin{array}{l}-.44 \\
(.02)\end{array}$ & $\begin{array}{l}-.06 \\
(.01)\end{array}$ & $\begin{array}{l}-.06 \\
(.01)\end{array}$ \\
\hline $\begin{array}{l}\text { Log product of land } \\
\text { area }\end{array}$ & $\begin{array}{l}-.18 \\
(.01) \\
\end{array}$ & $\begin{array}{l}-.18 \\
(.01)\end{array}$ & $\begin{array}{l}-.18 \\
(.01)\end{array}$ & $\begin{array}{l}-.17 \\
(.01)\end{array}$ & $\begin{array}{l}-.17 \\
(.01)\end{array}$ \\
\hline Adjacency $(0,1)$ & $\begin{array}{l}.72 \\
(.12)\end{array}$ & $\begin{array}{l}.72 \\
(.12)\end{array}$ & $\begin{array}{l}.72 \\
(.12)\end{array}$ & $\begin{array}{l}.73 \\
(.12)\end{array}$ & $\begin{array}{l}.73 \\
(.12)\end{array}$ \\
\hline $\begin{array}{l}\text { Number of landlocked } \\
\text { in pair }(0,1,2)\end{array}$ & $\begin{array}{l}-.29 \\
(.04)\end{array}$ & $\begin{array}{l}-.29 \\
(.04)\end{array}$ & $\begin{array}{l}-.3 \\
(.04)\end{array}$ & $\begin{array}{l}-.42 \\
(.04)\end{array}$ & $\begin{array}{l}-.42 \\
(.04)\end{array}$ \\
\hline $\begin{array}{l}\text { Common language: } \\
\text { Frankel-Rose }(0,1)\end{array}$ & & & $\begin{array}{l}.06 \\
(.1)\end{array}$ & & \\
\hline $\begin{array}{l}\text { Open-circuit } \\
\text { communication }(0,1)\end{array}$ & $\begin{array}{c}.28 \\
(.08) \\
\end{array}$ & & $\begin{array}{l}.26 \\
(.09)\end{array}$ & $\begin{array}{l}.37 \\
(.08)\end{array}$ & \\
\hline Direct communication & $\begin{array}{l}.46 \\
(.13)\end{array}$ & & $\begin{array}{l}.43 \\
(.14)\end{array}$ & $\begin{array}{l}.35 \\
(.13)\end{array}$ & \\
\hline Common language & & $\begin{array}{l}.69 \\
(.07)\end{array}$ & & & $\begin{array}{r}.73 \\
(.07)\end{array}$ \\
\hline $\begin{array}{l}\text { Product of linguistic } \\
\text { diversity }\end{array}$ & $\begin{array}{c}.93 \\
(.11) \\
\end{array}$ & $\begin{array}{l}.91 \\
(.11)\end{array}$ & $\begin{array}{c}.93 \\
(.11)\end{array}$ & $\begin{array}{l}.57 \\
(.11)\end{array}$ & $\begin{array}{l}.58 \\
(.11)\end{array}$ \\
\hline $\begin{array}{l}\text { Product of literacy } \\
\text { rate }\end{array}$ & $\begin{array}{l}.37 \\
(.11)\end{array}$ & $\begin{array}{c}38 \\
(.11)\end{array}$ & $\begin{array}{l}.37 \\
(.11)\end{array}$ & $\begin{array}{l}1.81 \\
(.09)\end{array}$ & $\begin{array}{l}1.81 \\
(.09)\end{array}$ \\
\hline Currency union $(0,1)$ & $\begin{array}{l}1.38 \\
(.18)\end{array}$ & $\begin{array}{l}1.39 \\
(.18)\end{array}$ & $\begin{array}{l}1.37 \\
(.18)\end{array}$ & $\begin{array}{l}1.23 \\
(.19)\end{array}$ & $\begin{array}{l}1.23 \\
(.19)\end{array}$ \\
\hline Political union $(0,1)$ & $\begin{array}{l}.71 \\
(.45) \\
\end{array}$ & $\begin{array}{l}.74 \\
(.45)\end{array}$ & $\begin{array}{l}.73 \\
(.45)\end{array}$ & $\begin{array}{l}.76 \\
(.44)\end{array}$ & $\begin{array}{l}.75 \\
(.44)\end{array}$ \\
\hline Free trade area $(0,1)$ & $\begin{array}{c}1 \\
(.1)\end{array}$ & $\begin{array}{l}1.02 \\
(.1)\end{array}$ & $\begin{array}{c}1 \\
(.1)\end{array}$ & $\begin{array}{l}1.12 \\
(.09)\end{array}$ & $\begin{array}{l}1.12 \\
(.09)\end{array}$ \\
\hline $\begin{array}{l}\text { Ex-colonial } \\
\text { relationship }(0,1)\end{array}$ & $\begin{array}{l}1.98 \\
(.13)\end{array}$ & $\begin{array}{l}1.97 \\
(.13)\end{array}$ & $\begin{array}{l}1.97 \\
(.13)\end{array}$ & $\begin{array}{l}2.02 \\
(.12)\end{array}$ & $\begin{array}{l}2.02 \\
(.12)\end{array}$ \\
\hline $\begin{array}{l}\text { Ex-common-colonizer } \\
(0,1)\end{array}$ & $\begin{array}{c}.43 \\
(.09)\end{array}$ & $\begin{array}{c}.41 \\
(.08)\end{array}$ & $\begin{array}{c}.42 \\
(.09)\end{array}$ & $\begin{array}{l}.21 \\
(.09)\end{array}$ & $\begin{array}{c}.21 \\
(.08)\end{array}$ \\
\hline $\mathbf{R}^{2}$ & .65 & .65 & .65 & .89 & .89 \\
\hline RMSE & 1.95 & 1.95 & 1.95 & 1.98 & 1.98 \\
\hline
\end{tabular}

Number of Observations: 31,010. Year-specific fixed effects are not reported. Robust standard errors in parentheses; corrections for clustering of country pairs. 
TABLE 4: ENGLISH AND OTHER EUROPEAN LANGUAGES

\begin{tabular}{|c|c|c|c|c|c|}
\hline \multicolumn{6}{|c|}{ REGRESSAND: Bilateral trade $\div$ product of GDP } \\
\hline $\begin{array}{l}\text { Log product of relative } \\
\text { distance }\end{array}$ & $\begin{array}{l}-.6 \\
(.02)\end{array}$ & $\begin{array}{l}-.62 \\
(.02)\end{array}$ & $\begin{array}{l}-.61 \\
(.02)\end{array}$ & $\begin{array}{l}-.61 \\
(.02)\end{array}$ & $\begin{array}{l}-.6 \\
(.02)\end{array}$ \\
\hline $\begin{array}{l}\text { Log product of } \\
\text { remoteness }\end{array}$ & $\begin{array}{l}-.54 \\
(.08)\end{array}$ & $\begin{array}{l}-.56 \\
(.08)\end{array}$ & $\begin{array}{l}-.55 \\
(.08)\end{array}$ & $\begin{array}{l}-.58 \\
(.08)\end{array}$ & $\begin{array}{l}-.58 \\
(.08)\end{array}$ \\
\hline $\begin{array}{l}\text { Log North-South } \\
\text { Difference }\end{array}$ & $\begin{array}{l}.25 \\
(.02)\end{array}$ & $\begin{array}{l}.26 \\
(.02) \\
\end{array}$ & $\begin{array}{l}.25 \\
(.02)\end{array}$ & $\begin{array}{l}.25 \\
(.02)\end{array}$ & $\begin{array}{l}.25 \\
(.02) \\
\end{array}$ \\
\hline $\begin{array}{l}\text { Log product of } \\
\text { Population }\end{array}$ & $\begin{array}{l}-.06 \\
(.01)\end{array}$ & $\begin{array}{l}-.07 \\
(.01)\end{array}$ & $\begin{array}{l}-.07 \\
(.01)\end{array}$ & $\begin{array}{l}-.07 \\
(.01)\end{array}$ & $\begin{array}{l}-.06 \\
(.01)\end{array}$ \\
\hline Log product of land area & $\begin{array}{l}-.17 \\
(.01)\end{array}$ & $\begin{array}{l}-.16 \\
(.01)\end{array}$ & $\begin{array}{l}-.17 \\
(.01)\end{array}$ & $\begin{array}{l}-.17 \\
(.01)\end{array}$ & $\begin{array}{l}-.17 \\
(.01)\end{array}$ \\
\hline Adjacency $(0,1)$ & $\begin{array}{l}.73 \\
(.12)\end{array}$ & $\begin{array}{l}.77 \\
(.12)\end{array}$ & $\begin{array}{l}.74 \\
(.12)\end{array}$ & $\begin{array}{l}.74 \\
(.12)\end{array}$ & $\begin{array}{l}.74 \\
(.12)\end{array}$ \\
\hline $\begin{array}{l}\text { Number of landlocked in } \\
\text { pair }(0,1,2)\end{array}$ & $\begin{array}{l}-.42 \\
(.04)\end{array}$ & $\begin{array}{l}-.41 \\
(.04)\end{array}$ & $\begin{array}{l}-.41 \\
(.04)\end{array}$ & $\begin{array}{l}-.43 \\
(.04)\end{array}$ & $\begin{array}{l}-.43 \\
(.04) \\
\end{array}$ \\
\hline $\begin{array}{l}\text { Open-circuit communi- } \\
\text { cation: English }(0,1)\end{array}$ & & $\begin{array}{c}.33 \\
(.09)\end{array}$ & $\begin{array}{l}.19 \\
(.09)\end{array}$ & & \\
\hline $\begin{array}{l}\text { Open-circuit communi- } \\
\text { cation: European }(0,1)\end{array}$ & & & & $\begin{array}{c}.44 \\
(.08)\end{array}$ & \\
\hline $\begin{array}{l}\text { Open-circuit } \\
\text { communication }(0,1)\end{array}$ & $\begin{array}{l}.37 \\
(.08)\end{array}$ & & $\begin{array}{l}.28 \\
(.09)\end{array}$ & & \\
\hline Direct communication & $\begin{array}{l}.35 \\
(.13)\end{array}$ & $\begin{array}{l}.61 \\
(.1)\end{array}$ & $\begin{array}{c}.36 \\
(.13)\end{array}$ & $\begin{array}{c}.33 \\
(.12) \\
\end{array}$ & \\
\hline Common Language* & & & & & $\begin{array}{c}.81 \\
(.08)\end{array}$ \\
\hline $\begin{array}{l}\text { Product of linguistic } \\
\text { diversity }\end{array}$ & $\begin{array}{l}.57 \\
(.11)\end{array}$ & $\begin{array}{l}.58 \\
(.11)\end{array}$ & $\begin{array}{l}.55 \\
(.11)\end{array}$ & $\begin{array}{c}.57 \\
(.11)\end{array}$ & $\begin{array}{l}.57 \\
(.11) \\
\end{array}$ \\
\hline Product of literacy rate & $\begin{array}{l}1.81 \\
(.09)\end{array}$ & $\begin{array}{l}1.75 \\
(.09)\end{array}$ & $\begin{array}{l}1.79 \\
(.09)\end{array}$ & $\begin{array}{l}1.79 \\
(.09)\end{array}$ & $\begin{array}{l}1.79 \\
(.09)\end{array}$ \\
\hline Currency union $(0,1)$ & $\begin{array}{l}1.23 \\
(.19)\end{array}$ & $\begin{array}{l}1.26 \\
(.19)\end{array}$ & $\begin{array}{l}1.26 \\
(.19)\end{array}$ & $\begin{array}{l}1.19 \\
(.19)\end{array}$ & $\begin{array}{l}1.19 \\
(.19)\end{array}$ \\
\hline Political union $(0,1)$ & $\begin{array}{l}.76 \\
(.44)\end{array}$ & $\begin{array}{l}.76 \\
(.47)\end{array}$ & $\begin{array}{l}.78 \\
(.45)\end{array}$ & $\begin{array}{l}.75 \\
(.44)\end{array}$ & $\begin{array}{l}.75 \\
(.44)\end{array}$ \\
\hline Free trade area $(0,1)$ & $\begin{array}{l}1.12 \\
(.09)\end{array}$ & $\begin{array}{l}1.02 \\
(.09)\end{array}$ & $\begin{array}{l}1.09 \\
(.09)\end{array}$ & $\begin{array}{c}1.1 \\
(.09)\end{array}$ & $\begin{array}{c}1.1 \\
(.09)\end{array}$ \\
\hline $\begin{array}{l}\text { Ex-colonial } \\
\text { relationship }(0,1)\end{array}$ & $\begin{array}{l}2.02 \\
(.12)\end{array}$ & $\begin{array}{l}2.04 \\
(.13)\end{array}$ & $\begin{array}{c}2 \\
(.13) \\
\end{array}$ & $\begin{array}{l}1.98 \\
(.12)\end{array}$ & $\begin{array}{l}1.98 \\
(.12) \\
\end{array}$ \\
\hline $\begin{array}{l}\text { Ex-common-colonizer } \\
(0,1)\end{array}$ & $\begin{array}{l}.21 \\
(.09)\end{array}$ & $\begin{array}{c}.23 \\
(.09)\end{array}$ & $\begin{array}{l}.18 \\
(.09)\end{array}$ & $\begin{array}{l}.18 \\
(.09)\end{array}$ & $\begin{array}{c}.18 \\
(.09)\end{array}$ \\
\hline $\mathbf{R}^{2}$ & .89 & .89 & .89 & .89 & .89 \\
\hline RMSE & 1.9825 & 1.9829 & 1.9821 & 1.9815 & 1.9815 \\
\hline
\end{tabular}

Number of Observations: 31,010. Year-specific fixed effects are not reported. Robust standard errors in parentheses; corrections for clustering of country pairs. 
TABLE 5: FURTHER TESTS

\begin{tabular}{|c|c|c|c|c|}
\hline \multicolumn{5}{|c|}{ REGRESSAND: Bilateral trade $\div$ product of GDP } \\
\hline $\begin{array}{l}\text { Log product of relative } \\
\text { distance }\end{array}$ & $\begin{array}{l}-.61 \\
(.02)\end{array}$ & $\begin{array}{l}-.61 \\
(.02)\end{array}$ & $\begin{array}{l}-.61 \\
(.02)\end{array}$ & $\begin{array}{l}-.69 \\
(.02)\end{array}$ \\
\hline $\begin{array}{l}\text { Log product of } \\
\text { remoteness }\end{array}$ & $\begin{array}{l}-.62 \\
(.08)\end{array}$ & $\begin{array}{l}-.62 \\
(.08)\end{array}$ & $\begin{array}{l}-.61 \\
(.08)\end{array}$ & \\
\hline $\begin{array}{l}\text { Log North-South } \\
\text { Difference }\end{array}$ & $\begin{array}{c}.24 \\
(.02) \\
\end{array}$ & $\begin{array}{c}.24 \\
(.02) \\
\end{array}$ & $\begin{array}{l}.24 \\
(.02) \\
\end{array}$ & $\begin{array}{r}.19 \\
(.02) \\
\end{array}$ \\
\hline $\begin{array}{l}\text { Log product of } \\
\text { Population }\end{array}$ & $\begin{array}{l}-.03 \\
(.01)\end{array}$ & $\begin{array}{l}-.03 \\
(.01)\end{array}$ & $\begin{array}{l}-.03 \\
(.01)\end{array}$ & \\
\hline Log product of land area & $\begin{array}{l}-.17 \\
(.01)\end{array}$ & $\begin{array}{l}-.17 \\
(.01)\end{array}$ & $\begin{array}{l}-.17 \\
(.01) \\
\end{array}$ & \\
\hline Adjacency $(0,1)$ & $\begin{array}{r}.79 \\
(.12) \\
\end{array}$ & $\begin{array}{l}.79 \\
(.12) \\
\end{array}$ & $\begin{array}{l}.76 \\
(.12) \\
\end{array}$ & $\begin{array}{l}.54 \\
(.13) \\
\end{array}$ \\
\hline $\begin{array}{l}\text { Number of landlocked in } \\
\text { pair }(0,1,2)\end{array}$ & $\begin{array}{l}-.38 \\
(.04)\end{array}$ & $\begin{array}{l}-.38 \\
(.04)\end{array}$ & $\begin{array}{l}-.38 \\
(.04)\end{array}$ & \\
\hline $\begin{array}{l}\text { Open-circuit Communi- } \\
\text { cation: European }(0,1)\end{array}$ & & & & $\begin{array}{r}.24 \\
(0.7)\end{array}$ \\
\hline Direct Communication & & & & $\begin{array}{r}.82 \\
(.11) \\
\end{array}$ \\
\hline Common Language* & $\begin{array}{l}.67 \\
(.08)\end{array}$ & $\begin{array}{l}.37 \\
(.17)\end{array}$ & $\begin{array}{l}.41 \\
(.2)\end{array}$ & \\
\hline $\begin{array}{l}\text { Network externality } \\
\text { from within }\end{array}$ & & $\begin{array}{c}.013 \\
(.006)\end{array}$ & $\begin{array}{c}.016 \\
(.012)\end{array}$ & \\
\hline $\begin{array}{l}\text { Network externality } \\
\text { from outside }\end{array}$ & & & $\begin{array}{l}-.004 \\
(.014)\end{array}$ & \\
\hline $\begin{array}{l}\text { Product of linguistic } \\
\text { diversity }\end{array}$ & $\begin{array}{c}.68 \\
(.12)\end{array}$ & $\begin{array}{l}.66 \\
(.12)\end{array}$ & $\begin{array}{l}.66 \\
(.12)\end{array}$ & \\
\hline Product of literacy rate & $\begin{array}{l}1.67 \\
(.1)\end{array}$ & $\begin{array}{l}1.66 \\
(.1)\end{array}$ & $\begin{array}{l}1.66 \\
(.1)\end{array}$ & \\
\hline Currency union $(0,1)$ & $\begin{array}{l}1.39 \\
(.19) \\
\end{array}$ & $\begin{array}{l}1.46 \\
(.19) \\
\end{array}$ & $\begin{array}{l}1.47 \\
(.2) \\
\end{array}$ & $\begin{array}{l}1.11 \\
(.22) \\
\end{array}$ \\
\hline Political union $(0,1)$ & $\begin{array}{l}1.18 \\
(.45)\end{array}$ & $\begin{array}{l}1.22 \\
(.45)\end{array}$ & $\begin{array}{c}1.2 \\
(.45)\end{array}$ & $\begin{array}{c}.86 \\
(.41)\end{array}$ \\
\hline Free trade area $(0,1)$ & $\begin{array}{l}1.3 \\
(.1)\end{array}$ & $\begin{array}{l}1.34 \\
(.1)\end{array}$ & $\begin{array}{l}1.35 \\
(.1)\end{array}$ & $\begin{array}{l}.55 \\
(.14)\end{array}$ \\
\hline $\begin{array}{l}\text { Ex-colonial } \\
\text { relationship }(0,1)\end{array}$ & $\begin{array}{l}1.45 \\
(.13)\end{array}$ & $\begin{array}{l}1.42 \\
(.13)\end{array}$ & $\begin{array}{l}1.42 \\
(.13)\end{array}$ & $\begin{array}{l}1.52 \\
(.12)\end{array}$ \\
\hline $\begin{array}{l}\text { Ex-common-colonizer } \\
(0,1)\end{array}$ & $\begin{array}{l}.31 \\
(.09) \\
\end{array}$ & $\begin{array}{l}.29 \\
(.09) \\
\end{array}$ & $\begin{array}{c}.3 \\
(.09) \\
\end{array}$ & $\begin{array}{l}.66 \\
(.09) \\
\end{array}$ \\
\hline $\begin{array}{l}\text { Common language*/ } \\
\text { outsider }\end{array}$ & $\begin{array}{c}-.2 \\
(.05)\end{array}$ & $\begin{array}{l}-.19 \\
(.05)\end{array}$ & $\begin{array}{l}-.19 \\
(.05)\end{array}$ & $\begin{array}{l}-.02 \\
(.05)\end{array}$ \\
\hline $\begin{array}{l}\text { Currency union/ } \\
\text { outsider }(0,1)\end{array}$ & $\begin{array}{l}.34 \\
(.04)\end{array}$ & $\begin{array}{l}.34 \\
(.04)\end{array}$ & $\begin{array}{l}.34 \\
(.04)\end{array}$ & $\begin{array}{c}.11 \\
(0.8)\end{array}$ \\
\hline $\begin{array}{l}\text { Political union/outsider } \\
(0,1)\end{array}$ & $\begin{array}{l}.31 \\
(.05)\end{array}$ & $\begin{array}{l}.31 \\
(.05)\end{array}$ & $\begin{array}{l}.31 \\
(.05)\end{array}$ & $\begin{array}{l}.16 \\
(.11)\end{array}$ \\
\hline FTA/outsider $(0,1)$ & $\begin{array}{c}.4 \\
(.05) \\
\end{array}$ & $\begin{array}{c}.4 \\
(.05) \\
\end{array}$ & $\begin{array}{c}.4 \\
(.05) \\
\end{array}$ & $\begin{array}{l}.15 \\
(.06) \\
\end{array}$ \\
\hline
\end{tabular}




\begin{tabular}{|c|c|c|c|c|}
\hline $\begin{array}{l}\text { Ex-colony/colonizer/ } \\
\text { outsider (0,1) }\end{array}$ & -.01 & -.01 & -.01 & -.05 \\
\hline $\mathbf{R}^{\mathbf{2}}$ & $(.04)$ & $(.04)$ & $(.04)$ & $(.04)$ \\
\hline RMSE & 0.89 & 0.89 & 0.89 & 0.91 \\
\hline
\end{tabular}

Number of Observations: 31,010. Year-specific fixed effects are not reported. Nor are country-specific fixed effects in the last column. Robust standard errors in parentheses; corrections for clustering of country pairs. 


\section{APPENDIX}

\section{THE LANGUAGE DATA*}

\section{COUNTRY}

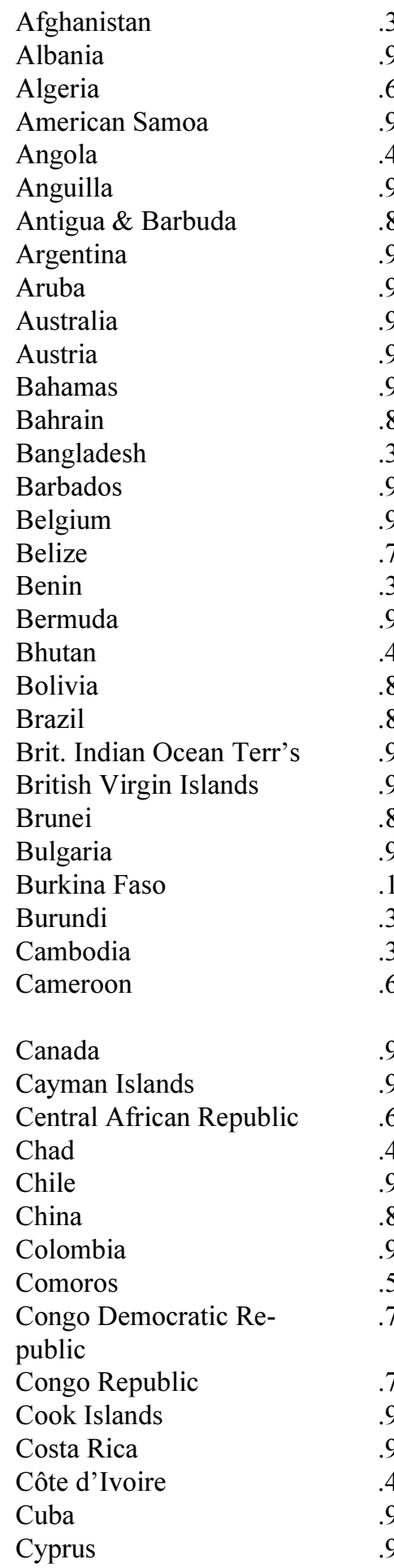

$\begin{array}{ccc}\text { LIT- } & \text { DIVER- } & \text { LANGUAGES } \\ \text { ERACY } & \text { SITY } & \text { (Frankel-Rose) }\end{array}$

.7

.93

.62

.97

.42

$$
.26
$$$$
.31
$$$$
.12
$$$$
.76
$$$$
0
$$$$
0
$$$$
.21
$$$$
\begin{array}{r}
21 \\
0
\end{array}
$$$$
.13
$$$$
.14
$$$$
.01
$$$$
.53
$$$$
.31
$$$$
.09
$$$$
.65
$$$$
.70
$$$$
.90
$$$$
0
$$$$
.82
$$$$
.68
$$$$
.03
$$$$
0
$$$$
.24
$$$$
.45
$$$$
.22
$$$$
.76
$$$$
0
$$$$
.31
$$$$
.97
$$$$
.55
$$$$
.58
$$$$
.96
$$$$
.95
$$$$
.60
$$$$
.48
$$$$
.03
$$$$
.01
$$$$
.92
$$

\section{.61}

.37

.04

.91

0

.37
English

Dutch, French

English

French

French

French

French, English

English, French

French

French

Spanish

Chinese

Spanish

French, Arabic

French
OPEN-CIRCUIT

LANGUAGES

\section{SPOKEN \\ LANGUAGES}

Persian

Arabic, French

English

Portuguese

English

English

Spanish

Dutch, Spanish

English

German

English

Arabic

English

Dutch, French

English, Spanish

French

English

Spanish

Portuguese

English

English

Malay, English

Turkish

French

French

French, English

English, French

English

French

Arabic, French

Spanish

Chinese

Spanish

French, Arabic

French

$\begin{array}{cl}\text { French } & \text { French } \\ \text { English } & \text { English } \\ \text { Spanish } & \text { Spanish } \\ \text { French } & \text { French } \\ - & \text { Spanish } \\ - & \text { Greek, Turkish }\end{array}$

Pashto .45 Persian .4

Albanian .98

Arabic .83 French .2

English .97

Portuguese .42

English 1

English 1

Spanish .92 Italian .04

Spanish .74

English .99

German .98

English .98

Arabic .85

English .97

Dutch .56 French .56

English .93 Spanish .35

French .37

English 1

Nepali .08

Spanish .44 Quechua .36

Portuguese .95

English 1

English .98

Malay .88 English .05

Turkish .09

French .19

French .35

French .42 Fulfulde .30

English .21 Fang .05

English .65 French .22

English .98

French .6

Arabic .5 French .48

Spanish .93

Chinese .84

Spanish .84

French .3 Arabic .3

French $\quad .58$ Swahili .17

Lingala .12

French .7 Lingala .12

English .93

Spanish .87

French .48

Spanish .91

Greek .75 Turkish .20 


\begin{tabular}{|c|c|c|c|c|c|}
\hline COUNTRY & $\begin{array}{c}\text { LIT- } \\
\text { ERACY }\end{array}$ & $\begin{array}{l}\text { DIVER- } \\
\text { SITY }\end{array}$ & $\begin{array}{l}\text { LANGUAGES } \\
\text { (Frankel-Rose) }\end{array}$ & $\begin{array}{l}\text { OPEN-CIRCUIT } \\
\text { LANGUAGES }\end{array}$ & $\begin{array}{c}\text { SPOKEN } \\
\text { LANGUAGES }\end{array}$ \\
\hline Czech Republic & .99 & .06 & - & - & - \\
\hline Czechoslovakia & .99 & .11 & - & - & Hungarian .04 \\
\hline Denmark & .99 & .05 & - & Danish, German & Danish 1 \\
\hline Djibouti & .46 & .58 & French, Arabic & French, Arabic & French .46 Arabic .11 \\
\hline Dominica & .94 & 0 & English & English, French & English 1 French .7 \\
\hline Dominican Republic & .82 & .05 & Spanish & Spanish & Spanish .87 \\
\hline Ecuador & .9 & .26 & Spanish & Spanish & Spanish .79 Quechua .12 \\
\hline Egypt Arab Republic & .51 & .46 & Arabic & Arabic & Arabic .97 \\
\hline El Salvador & .71 & 0 & Spanish & Spanish & Spanish .92 \\
\hline Ethiopia & .35 & .84 & - & English & English .35 \\
\hline Faeroe Islands & .99 & 0 & - & Danish & Danish 1 \\
\hline Falkland Islands & - & 0 & - & English & English 1 \\
\hline Fiji & .92 & .60 & English & English & English .92 \\
\hline Finland & .99 & .14 & Swedish & Swedish & Swedish .12 \\
\hline France & .99 & .24 & French & French & French .99 \\
\hline French Guiana & .83 & .47 & - & French & French .83 \\
\hline French So. Antarc.Terr's & 1 & 0 & French & French & French 1 \\
\hline Gabon & .63 & .53 & French & French & French .63 Fang .29 \\
\hline Gambia & .39 & .73 & English & English & English .39 Fulfulde .17 \\
\hline Germany, West & .99 & .18 & German & German & German .99 \\
\hline Germany, East & .99 & .18 & German & German & German .99 \\
\hline Ghana & .64 & .79 & English & English & English .48 \\
\hline Gibraltar & .80 & .50 & - & Spanish, English & Spanish .88 English .13 \\
\hline Greece & .95 & .14 & - & Greek & Greek .99 \\
\hline Greenland & .93 & .27 & - & Danish & Danish .93 \\
\hline Grenada & .98 & 0 & English & English & English .98 \\
\hline Guadeloupe & .90 & 0 & - & French & French 1 \\
\hline Guam & .99 & .64 & English & English & English .99 \\
\hline Guatemala & .56 & .60 & Spanish & Spanish & Spanish .44 \\
\hline Guinea & .35 & .75 & French & French & French .35 Fulfulde .04 \\
\hline Guinea-Bissau & .54 & .85 & Portuguese & Portuguese & Portuguese .54 \\
\hline Guyana & .98 & .07 & English & English & English .98 \\
\hline Haiti & .45 & 0 & French & French & French 1 \\
\hline Honduras & .73 & .05 & Spanish & Spanish & Spanish .92 \\
\hline Hong Kong & .92 & .48 & Chinese, English & Chinese, English & Chinese .95 \\
\hline Hungary & .99 & .14 & - & - & Hungarian .98 \\
\hline Iceland & .99 & 0 & - & - & - \\
\hline India & .52 & .93 & English & Hindi, English & $\begin{array}{l}\text { Hindi } .50 \text { Tamil } .07 \\
\text { Urdu } .05\end{array}$ \\
\hline Indonesia & .84 & .83 & - & - & Javanese .42 Malay .06 \\
\hline Iran & .72 & .76 & - & Persian & Persian .36 \\
\hline Iraq & .58 & .65 & Arabic & Arabic & Arabic .58 \\
\hline Ireland & .98 & .17 & English & English & English .99 \\
\hline Israel & .95 & .65 & - & English & Arabic .12 \\
\hline Italy & .98 & .59 & - & - & Italian .98 \\
\hline Jamaica & .85 & .01 & English & English & English 1 \\
\hline Japan & .99 & .03 & . & - & - \\
\hline Jordan & .87 & .48 & Arabic & Arabic & Arabic .87 \\
\hline Kenya & .78 & .90 & - & English, Arabic & Swahili .78 English .40 \\
\hline Kiribati & .90 & .03 & English & English & English .90 \\
\hline Korea Democratic Rep. & .99 & 0 & - & - & - \\
\hline Korea Republic & .98 & 0 & - & - & - \\
\hline Kuwait & .79 & .54 & Arabic & Arabic & Arabic 1 \\
\hline
\end{tabular}




\begin{tabular}{|c|c|c|c|c|c|}
\hline COUNTRY & $\begin{array}{l}\text { LIT- } \\
\text { ERACY }\end{array}$ & $\begin{array}{l}\text { DIVER- } \\
\text { SITY }\end{array}$ & $\begin{array}{l}\text { LANGUAGES } \\
\text { (Frankel-Rose) }\end{array}$ & $\begin{array}{l}\text { OPEN-CIRCUIT } \\
\text { LANGUAGES }\end{array}$ & $\begin{array}{c}\text { SPOKEN } \\
\text { LANGUAGES }\end{array}$ \\
\hline Laos & .57 & .56 & - & - & - \\
\hline Lebanon & .86 & .14 & - & Arabic, French & Arabic .93 French .65 \\
\hline Liberia & .38 & .91 & English & English & English .64 \\
\hline Libya & .76 & .35 & - & Arabic & Arabic .96 \\
\hline Madagascar & .80 & .50 & French & French & French .80 \\
\hline Malawi & .58 & .70 & English & English & English .58 \\
\hline Malaysia & .83 & .75 & Chinese & Malay, Chinese & Malay .50 Chinese .2 \\
\hline Maldives & .93 & .01 & - & - & - \\
\hline Mali & .31 & .86 & French & French & French .31 Fulfulde .11 \\
\hline Malta & .88 & .02 & English & English & English .88 \\
\hline Martinique & .93 & 0 & French & French & French 1 \\
\hline Mauritania & .38 & .19 & French & Arabic & Arabic .38 Fulfulde .06 \\
\hline Mauritius & .83 & .60 & English & French, English & French $.83 \mathrm{Urdu} .06$ \\
\hline Mexico & .90 & .13 & Spanish & Spanish & Spanish .88 \\
\hline Mongolia & .83 & .30 & - & - & - \\
\hline Montserrat & .97 & 0 & English & English & English 1 \\
\hline Morocco & .44 & .47 & Arabic & Arabic, French & Arabic .65 \\
\hline Mozambique & .40 & .92 & Portuguese & Portuguese & Portuguese .27 \\
\hline Myanmar & .83 & .64 & - & - & - \\
\hline Nauru & .99 & .57 & - & English & English .65 \\
\hline Nepal & .27 & .69 & - & - & Nepali .7 \\
\hline Netherlands & .99 & .20 & Dutch & Dutch & Dutch .99 \\
\hline Netherlands Antilles & .98 & .12 & - & Dutch, Spanish & Dutch .98 Spanish .84 \\
\hline New Caledonia & .91 & .84 & - & French & French .91 \\
\hline New Zealand & .99 & .10 & English & English & English .99 \\
\hline Nicaragua & .66 & .08 & Spanish & Spanish & Spanish .92 \\
\hline Niger & .14 & .64 & French & French, Arabic & $\begin{array}{l}\text { Hausa } .50 \text { French } .14 \\
\text { Arabic } .14 \text { Fulfulde } .08\end{array}$ \\
\hline Nigeria & .57 & .88 & English & English & Hausa .46 \\
\hline Niue & .95 & 0 & English & English & English 1 \\
\hline Norway & .99 & .08 & - & - & -5 \\
\hline Oman & .80 & .68 & Arabic & Arabic & Arabic .90 \\
\hline Pakistan & .38 & .83 & - & English & Urdu .7 Pashto .08 \\
\hline Panama & .91 & .23 & Spanish & Spanish & Spanish .77 \\
\hline Papua New Guinea & .72 & .99 & - & English & English .72 \\
\hline Paraguay & .92 & .33 & Spanish & Spanish & Spanish .92 Portuguese .12 \\
\hline Peru & .89 & .35 & Spanish & Spanish & Spanish .8 Quechua .17 \\
\hline Philippines & .95 & .85 & English & English & English .52 \\
\hline Poland & .99 & .12 & - & - & - \\
\hline Portugal & .87 & .02 & Portuguese & Portuguese & Portuguese 1 \\
\hline Qatar & .79 & .57 & Arabic & Arabic, Persian & Arabic .79 Persian .23 \\
\hline Reunion & .79 & .09 & French & French & French 1 Tamil .18 \\
\hline Romania & .97 & .20 & - & - & Hungarian .11 \\
\hline Russia & .98 & .27 & - & - & - \\
\hline Rwanda & .60 & 0 & French, English & French, English & French .5 English .5 \\
\hline Samoa & .97 & 0 & English & English & English .97 \\
\hline Saudi Arabia & .63 & .56 & Arabic & Arabic & Arabic .82 \\
\hline Senegal & .33 & .77 & French & French & French .3 Fulfulde .23 \\
\hline Seychelles & .58 & .07 & - & French, English & French .95 English .58 \\
\hline Sierra Leone & .31 & .82 & English & English & English .31 \\
\hline Singapore & .91 & .74 & Chinese, English & Chinese, English & $\begin{array}{l}\text { Chinese } .51 \text { English } .27 \\
\text { Malay .16 }\end{array}$ \\
\hline Solomon Islands & .32 & .97 & English & English & English .32 \\
\hline Somalia & .24 & .2 & Arabic & Arabic, English & English .18 \\
\hline
\end{tabular}




\begin{tabular}{|c|c|c|c|c|c|}
\hline COUNTRY & $\begin{array}{l}\text { LIT- } \\
\text { ERACY }\end{array}$ & $\begin{array}{l}\text { DIVER- } \\
\text { SITY }\end{array}$ & $\begin{array}{l}\text { LANGUAGES } \\
\text { (Frankel-Rose) }\end{array}$ & $\begin{array}{c}\text { OPEN-CIRCUIT } \\
\text { LANGUAGES }\end{array}$ & $\begin{array}{c}\text { SPOKEN } \\
\text { LANGUAGES }\end{array}$ \\
\hline South Africa & .82 & .87 & English & English & English .3 Hindi .05 \\
\hline Spain & .97 & .44 & Spanish & Spanish & Spanish .97 \\
\hline Sri Lanka & .90 & .31 & - & - & Tamil .16 \\
\hline St Helena & .97 & 0 & - & English & English 1 \\
\hline St Kitts \& Nevis & .97 & 0 & English & English & English 1 \\
\hline St Lucia & .54 & .67 & English & English, French & English 1 French .85 \\
\hline St Vincent \& Grenadines & .96 & 0 & English & English & English 1 \\
\hline St Pierre \& Miquelon & .99 & .07 & French & French & French 1 \\
\hline Sudan & .46 & .56 & Arabic & Arabic & Arabic .51 \\
\hline Suriname & .93 & .79 & Dutch & Dutch, Hindi & $\begin{array}{l}\text { Dutch } .93 \text { Hindi } .38 \\
\text { Javanese } .15\end{array}$ \\
\hline Sweden & .99 & .37 & Swedish & Swedish & Swedish .99 \\
\hline Switzerland & .99 & .53 & German, French & German, French & $\begin{array}{l}\text { German } .72 \text { French } .33 \\
\text { Italian } .07\end{array}$ \\
\hline Syria & .71 & .50 & Arabic & Arabic & Arabic .8 \\
\hline Taiwan & .91 & .49 & Chinese & Chinese & Chinese .91 \\
\hline Tanzania & .68 & .95 & English & English, Arabic & Swahili .93 English .05 \\
\hline Thailand & .94 & .75 & - & - & Malay .05 \\
\hline Togo & .52 & .89 & French & French & French .52 \\
\hline Tonga & .98 & .01 & - & English & English .98 \\
\hline Trinidad \& Tobago & .98 & .47 & English & English & English .98 \\
\hline Tunisia & .67 & .01 & Arabic & Arabic, French & Arabic .98 \\
\hline Turkey & .82 & .25 & - & Turkish & Turkish .9 \\
\hline Turks \& Caicos Islands & .98 & 0 & - & English & English 1 \\
\hline Tuvalu & .96 & .17 & English & English & - \\
\hline U.S.S.R. & .98 & .40 & - & - & - \\
\hline Uganda & .62 & .93 & English & English & English .62 \\
\hline United Arab Emirates & .79 & .78 & Arabic & Arabic & Arabic .89 \\
\hline United Kingdom & .99 & .07 & English & English & English .99 \\
\hline United States & .97 & .35 & English & English & English .97 Spanish .09 \\
\hline Uruguay & .97 & .09 & Spanish & Spanish & Spanish 1 \\
\hline Venezuela & .91 & .02 & Spanish & Spanish & Spanish .93 \\
\hline Vietnam & .94 & .20 & - & - & - \\
\hline Virgin Islands (U.S.) & .92 & .34 & English & English & English 1 \\
\hline Yemen & .38 & .56 & - & Arabic & Arabic .95 \\
\hline Yugoslavia & .91 & .32 & - & - & Albanian .16 \\
\hline Zambia & .78 & .9 & English & English & English .85 \\
\hline Zimbabwe & .85 & .56 & English & English & English .62 \\
\hline
\end{tabular}

*Languages (Frankel-Rose) is from Rose's database for Frankel and Rose (2002). Otherwise, all the data in this table is extracted from Grimes (2000) with ancillary use of the CIA Country Factbook (except in the one case of language diversity for Hong Kong, which is drawn from Taylor and Hudson (1972)). Literacy is from the CIA Factbook (with a few blanks filled in from Grimes). Language diversity is from Grimes. A zero for language diversity may mean that no calculation was made on the assumption that the number would be small (source: private correspondence). The percentage figures for the spoken languages are almost exclusively derived from Grimes. But some inferences depend on the literacy rates, in which case the CIA Factbook enters as well. Official languages come from Grimes (2000) (except for a few isolated entries drawn from the CIA Factbook). An OpenCircuit Language is either official or has at least $20 \%$ speakers, and the maximum number of Open-circuit Languages is two. A Spoken Language is spoken by at least $4 \%$. Some major national languages are omitted because they are neither accepted as official nor spoken by as many as $4 \%$ of the population in any trading country outside of the home one. Other languages do not appear because of missing trade data. This is notoriously true in regard to the languages in the ex-Soviet Union, including Russian. Persian refers to Farsi. Fulfulde is also sometimes referred to as Fula or Fulani. 